\title{
Silacyclohexanes, Sila(hetero)cyclohexanes and Related Compounds: Structure and Conformational Analysis
}

\author{
Bagrat A. Shainyan \\ A. E. Favorsky Irkutsk Institute of Chemistry, Siberian Branch of Russian Academy of Science, 1 Favorsky Street, \\ Irkutsk 664033, Russia; bagrat@irioch.irk.ru \\ Academic Editor: Maged Henary \\ Received: 10 March 2020; Accepted: 25 March 2020; Published: 1 April 2020 \\ check for \\ updates
}

\begin{abstract}
Conformational analysis of Si-mono- and Si,Si-disubstituted silacyclohexanes as well as their analogues with a heteroatom(s) in the ring is reviewed with the focus on the recent results. Experimental measurements in the gas phase (gas electron diffraction, GED) and low temperature NMR spectroscopy (LT NMR) on ${ }^{1} \mathrm{H},{ }^{13} \mathrm{C}$ and ${ }^{29} \mathrm{Si}$ nuclei are described along with theoretical calculations at the DFT and MP2 levels of theory. Structural and conformational specific features are shown to be principally different from those of the carbon predecessors-the corresponding cyclohexanes, oxanes, thianes and piperidines. The role of various effects (steric, hyperconjugation, stereoelectronic, electrostatic) is demonstrated.
\end{abstract}

Keywords: conformational analysis; structure; silicon-containing heterocycles; GED; LT NMR; theoretical calculations

\section{Introduction}

Conformational analysis of cyclohexanes is an inalienable part of organic chemistry that is familiar to all organic chemists, even to those whose interests lie outside this specific area. In going from cyclohexanes to their $\mathrm{N-}, \mathrm{O}-$, or S-heteroanalogues, no dramatic changes occur in the structure or conformational preferences of the substituents, which may give an illusion that this is true for all other heterocyclohexanes. However, this is not always so, as it became clear in the last 15 years, when a large number of silacyclohexanes with different groups at silicon, as well as having one or more other heteroatoms in the six-membered ring, such as $\mathrm{N}, \mathrm{O}, \mathrm{S}$, have been synthesized. The only review on the topic was that of 2004 [1] reporting a few compounds known at that time: silacyclohexane, 1,4-disilaand 1,3,5-trisilacylohexanes and their Si-alkyl derivatives. Since then only two reports published by the present author and reviewing specific questions appeared [2,3]. The nowadays state of the problem is unique in that, on the one hand, it still allows discussing all main findings in the field in one review, and, on the other hand, making solid conclusions based on ample experimental evidences. The studies using various experimental techniques, such as GED, LT NMR, Raman and IR spectroscopy and quantum chemical calculations showed a remarkable difference in the structure and conformational behavior between sila(hetero)cyclohexanes and cyclohexanes, piperidines, oxanes, or thianes. The present review summarizes the results of experimental and theoretical conformational studies on the title compounds in different aggregate states, and is focused on recent works in this field. All these issues will be addressed in the proposed review providing the reader with the answers to the raised questions. The list of references contains 93 items including those of 2019 year, most of them referring to the last decade. 


\section{General Features of Sila(hetero)cyclohexanes}

The three main issues in conformational analysis of cyclohexanes and all their derivatives are the ring conformation, the ratio of the conformers, and the barrier to their interconversion. As will be shown below, these three characteristics of sila(hetero)cyclohexanes drastically differ from those of cyclohexanes, piperidines, oxanes, or thianes.

As to the ring conformation, an important difference is a smaller angle of folding between the $\mathrm{C} 2 \mathrm{C} 3 \mathrm{C} 5 \mathrm{C} 6$ plane of the ring and the $\mathrm{C} 2 \mathrm{SiC} 6$ plane with respect to the $\mathrm{C} 3 \mathrm{C} 4 \mathrm{C} 5$ plane as depicted in Figure 1 . The same is true for the nitrogen, oxygen or sulfur-containing heterocycles, in which atom $\mathrm{C} 4$ is replaced by the corresponding heteroatom [4].

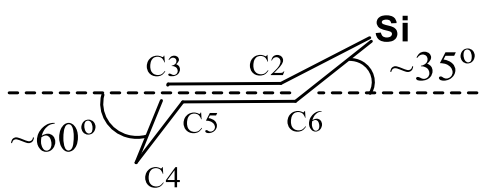

Figure 1. Lower degree of folding at silicon in the six-membered ring.

The ratio of the conformers is also dramatically different. It is determined by the relative conformational energies, $A$, defined for the $a x \leftrightarrows e q$ equilibrium as $A=-\Delta G^{\circ}=G_{\text {ax }}-G_{\text {eq }}$. For cyclohexanes, piperidines, oxanes, or thianes the $A$ values are always positive. For substituents at silicon they are much smaller and even may become negative. Most striking examples are practically equal $A$ values for $\mathrm{Me}$ and $\mathrm{Ph}$ groups at silicon (0.23 [5] and $0.25 \mathrm{kcal} / \mathrm{mol}$ [6]), whereas in the cyclohexane series they are strongly different (1.76 and $2.87 \mathrm{kcal} / \mathrm{mol}$ [7]), and the value of $A$ for very bulky but, at the same time, highly electronegative substituent $\mathrm{CF}_{3}$, which is positive and very large when it is attached to carbon $\left(2.50 \mathrm{kcal} / \mathrm{mol}\right.$ [8]) but becomes negative for $\mathrm{CF}_{3}$ at silicon falling in the range from -0.2 to $+0.5 \mathrm{kcal} / \mathrm{mol}$ [9]. The ring inversion barriers in silacyclohexanes and their analogues are much lower than those in the carbon predecessors. Normally, they are as low as $4.5-5.5 \mathrm{kcal} / \mathrm{mol}$, in comparison to $10-14 \mathrm{kcal} / \mathrm{mol}$ in cyclohexanes, piperidines, oxanes, or thianes. Such small barriers can be measured by NMR only by using special NMR probes working at very low temperatures, down to the interval from -180 to $-190^{\circ} \mathrm{C}$, and solvents, which are not frozen at these temperatures (mixtures of freons). Such low barriers are due to the flattened structure of sila(hetero)cyclohexanes (Figure 1), which is closer to the transition state structurally and, according to the Hammond postulate, energetically, and, hence, needs less energy to reach it.

Other differences of sila(hetero)cyclohexanes, like additivity of conformational effects versus nonadditivity in cyclohexanes, or opposite conformational preferences in gas and solution, having no precedents in classical conformational analysis, will be discussed below.

\section{Silacyclohexanes}

The conformational equilibrium of monosubstituted 1-X-silacyclohexanes 1 in Figure 2 can be shifted either to the axial or to the equatorial conformer, depending on the nature of substituent $X$. Therefore, the conformational energy of $\mathrm{X}, A(\mathrm{X})_{\mathrm{Si}}=-\Delta G=-\left(G_{\mathrm{eq}}-G_{\mathrm{ax}}\right)=\mathrm{RT} \log ([\mathrm{eq}] /[\mathrm{ax}])$, can be either positive or negative, in contrast to the corresponding cyclohexanes, in which $A(\mathrm{X})_{\mathrm{C}}$ is always positive, that is, the substituent always prefers the equatorial position. The available $A$ values for both series are summarized in Table 1.

The following conclusions can be made from analysis of the data in Table 1. First, a drastic decrease of all $A$ values in going from cyclohexanes to silacyclohexanes implies a minor, subordinate role of steric effects in silacyclohexanes. Second, inversion of the sign $(X=$ halogen $)$ or sharp decrease $\left(X=\mathrm{CF}_{3}\right)$ of the $A$ values of these electronegative groups is indicative of the determining role of electrostatic effects in the latter series. This is owing to the presence of strongly electropositive silicon atom in the molecule and is clearly manifested not only in the position of the equilibrium between the conformers but also in 
the lengths of the Si-C bonds. Thus, the $\mathrm{Si}-\mathrm{CF}_{3}$ bond in trifluoromethylsilacyclohexane is elongated by $\sim 0.08 \AA$ relative to the $\mathrm{Si}-\mathrm{CH}_{2}$ because of repulsion of the positively charged $\mathrm{Si}$ and $\mathrm{CF}_{3}$ carbon atoms.

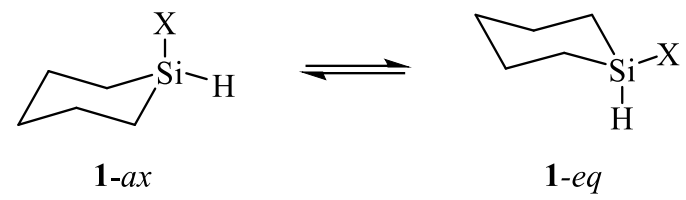

Figure 2. Conformational equilibrium of monosubstituted silacyclohexanes.

Table 1. Conformational energies $A(\mathrm{kcal} / \mathrm{mol})$ for different substituents at $\mathrm{C}$ and $\mathrm{Si}$ atoms.

\begin{tabular}{ccc}
\hline $\mathbf{X}$ & $A(\mathbf{X})_{\mathrm{C}}$ & $A(\mathbf{X})_{\mathrm{Si}}$ \\
\hline $\mathrm{F}$ & 0.36 & $-0.28[10]$ \\
$\mathrm{Cl}$ & 0.53 & $-0.43[11]$ \\
$\mathrm{Br}$ & 0.48 & $-0.82[12]$ \\
$\mathrm{I}$ & 0.49 & $-0.59[13]$ \\
$\mathrm{OH}$ & $0.6-1.0$ & $0.03[14]$ \\
$\mathrm{SiH}_{3}$ & $0.33^{\mathrm{a}}$ & $0.05[15]$ \\
$\mathrm{Me}$ & 1.76 & $0.23[5]$ \\
$\mathrm{CF}_{3}$ & 2.50 & $0.40[9]$ \\
$\mathrm{Ph}$ & 2.87 & $0.25[6]$ \\
$t-\mathrm{Bu}$ & 4.7 & $1.30[16]$ \\
\hline
\end{tabular}

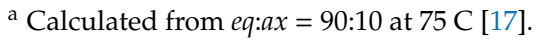

The same is true for the $\mathrm{Si}-\mathrm{CF}_{3}(1.934 \AA)$ and Si-Me bond in 1-methyl-1-silacyclohexane (1.862 $\AA$ ). The relative importance of steric, hyperconjugation and electrostatic effects was evaluated and discussed in detail in the author's review [3]. A minor role of steric effects not veiled by the effect of strongly electronegative groups (halogen, $\mathrm{CF}_{3}$ ) can be followed on the example of $\mathrm{X}=\mathrm{SiH}_{3}$. $\mathrm{Low}$ $A$ in silylcyclohexane (0.33) is, evidently, due to the long C-Si bond ( 1.85 $\AA$ ). Further lengthening in 1-silylsilacyclohexane [e.g., in $(t-\mathrm{BuSi})_{2}$ the length of the $\mathrm{Si}-\mathrm{Si}$ bond is $2.69 \AA$ ) makes the steric effect negligible $(A=0.05 \mathrm{kcal} / \mathrm{mol})$. The only substituent, for which steric effect could be significant in silacyclohexanes is $t$-butyl group, but until recently the only available compound of this type was the simplest representative, 1-t-butylsilacyclohexane. Very recently we have synthesized 1-t-butyl-1-phenylsilacyclohexane and investigated its conformational equilibrium (vide infra).

Introduction of a second substituent to silicon rises two interrelated questions in conformational analysis of geminally 1,1-disubstituted silacyclohexanes 2: (i) qualitative applicability of individual $A$ values of substituents $X$ and $Y$ for prediction of the position of conformational equilibrium in Figure 3 , and (ii) quantitative prediction of the conformer ratio on the basis of monosubstituted compounds (additivity or nonadditivity of conformational energies).
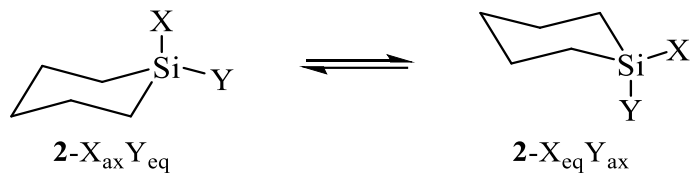

Figure 3. Conformational equilibrium of geminally 1,1-disubstituted silacyclohexanes.

It makes sense to compare the conformational behavior of geminally substituted cyclohexanes and silacyclohexanes. As is clearly seen from Table 2, there is neither quantitative nor even qualitative agreement between the conformational preferences in the mono and disubstituted cyclohexanes. The mean deviation $\Delta \Delta G^{\circ}$ of the experimental free energy difference $\Delta G^{\circ}$ ax-eq from that calculated by the additive scheme $\Delta G^{\circ}$ add for the presented selection of cyclohexanes is $>1 \mathrm{kcal} / \mathrm{mol}$, which is very large 
for conformational equilibria. The pairs of substituents for which the experimental and calculated values of $\Delta G^{\circ}$ have different sign, that is, the observed conformational preferences are opposite to those predicted from $A$ values for monosubstituted compounds, deserve special mention. The most striking example is 1-methyl-1-phenylcyclohexane, which, in view of the much larger conformational energy of the $\mathrm{Ph}$ as compared to Me group must exist exclusively as a $\mathrm{Me}_{\mathrm{ax}} \mathrm{Ph}_{\mathrm{eq}}$ conformer.

Table 2. Nonadditivity of conformational effects in cyclohexanes.

\begin{tabular}{|c|c|c|c|c|c|}
\hline$X$ & $\mathbf{Y}$ & $\Delta G_{\text {ax-eq }}^{\circ}$ & $\Delta G^{\circ}$ add & $\Delta \Delta G^{\circ}$ & Ref. \\
\hline $\mathrm{Me}$ & $\mathrm{F}$ & 0.86 & 1.60 & -0.74 & [18] \\
\hline $\mathrm{Me}$ & $\mathrm{CF}_{3}$ & 0.53 & 1.31 & -0.78 & [18] \\
\hline $\mathrm{Me}$ & $\mathrm{Ph}$ & 0.32 & -1.11 & 1.43 & {$[19,20]$} \\
\hline $\mathrm{Me}$ & $\mathrm{NMe}_{2}$ & -0.4 & 0.21 & -0.61 & [21] \\
\hline $\mathrm{Ph}$ & $\mathrm{NMe}_{2}$ & -0.5 & 1.34 & -1.84 & [22] \\
\hline $\mathrm{Me}$ & $\mathrm{OH}$ & 0.31 & 0.73 & -0.42 & {$[23,24]$} \\
\hline $\mathrm{Ph}$ & $\mathrm{OH}$ & 0.5 & 1.86 & -1.36 & [25] \\
\hline
\end{tabular}

However, as was found experimentally, the equilibrium of 1-methyl-1-phenylcyclohexane is substantially shifted to the $\mathrm{Me}_{\mathrm{eq}} \mathrm{Ph}_{\mathrm{ax}}$ conformer $\left(72: 28, \Delta G^{\circ}\right.$ ax-eq $=0.32$, Table 2) [26]. The reasons of such behavior have been clarified using high level quantum chemical calculations [20]. In the $\mathrm{Me}_{\mathrm{ax}} \mathrm{Ph}_{\mathrm{eq}}$ conformer, both Ph-'orthogonal' and Ph-'horizontal' rotamers are destabilized by repulsive interactions of ortho-protons with either the Me group or $\alpha-\mathrm{CH}_{\mathrm{eq}}$ protons, while in the Ph-'horizontal' rotamer of the $\mathrm{Me}_{\mathrm{eq}} \mathrm{Ph}_{\mathrm{ax}}$ conformer the latter destabilization is avoided. For the sake of fairness, it should be noted that there are examples of additivity of conformational effects in cyclohexanes [27,28], but in general, the conclusion about the absence of additivity of the $A$ values in geminally disubstituted cyclohexanes made ten years ago [18] is undoubtedly true.

At that time it was too bold to say anything about additivity or nonadditivity in silacyclohexane series because there only available examples were $\mathrm{Si}(\mathrm{Me}, \mathrm{F})$ - and $\mathrm{Si}\left(\mathrm{Me}, \mathrm{CF}_{3}\right)$-silacyclohexanes. Nevertheless, in the same work, Arnason et al. stated that for silacyclohexanes the model works remarkably well for this limited selection of substituents [18]. Since then, a good deal of studies devoted to conformational preferences in sila(hetero)cyclohexanes have seen the light, as summarized in Table 3. The analysis of Table 3 clearly shows that, if to exclude some specific cases with endocyclic $\mathrm{N}$ and $\mathrm{O}$ atoms in the ring (No. 10, 12 13, given in bold, which will be discussed below), averaging of other $\Delta \Delta G^{\circ}$ values results in the mean value of $0.1 \mathrm{kcal} / \mathrm{mol}$ for other 12 pairs of conformers, or more than one order of magnitude less than in Table 2 for cyclohexanes.

Therefore, the additivity model does work for silacyclohexanes without exceptions, and also for sila(hetero)cyclohexanes, unless the latter contain strongly electronegative atom or group in the ring. The exceptions deserve separate consideration, which allowed to reveal the influence of stereoelectronic and electrostatic effects in these specific cases. 
Table 3. Additivity of conformational effects in silacyclohexanes and sila(hetero)cyclohexanes.

\begin{tabular}{|c|c|c|c|c|c|c|c|}
\hline No. & $X$ & $\mathbf{Y}$ & $\mathbf{Z}$ & $\Delta G^{\circ}$ ax-eq & $\Delta G^{\circ}$ add & $\Delta \Delta G^{\circ}$ & Ref. \\
\hline 1 & $\mathrm{CH}_{2}$ & $\mathrm{Me}$ & $\mathrm{F}$ & 0.32 & 0.51 & -0.19 & [18] \\
\hline 2 & $\mathrm{CH}_{2}$ & $\mathrm{Me}$ & $\mathrm{CF}_{3}$ & 0.61 & 0.49 & 0.12 & [18] \\
\hline 3 & $\mathrm{CH}_{2}$ & $\mathrm{Me}$ & $\mathrm{Cl}$ & 0.36 & 0.36 & 0.00 & [29] \\
\hline 4 & $\mathrm{CH}_{2}$ & $\mathrm{Me}$ & $\mathrm{Ph}$ & 0.11 & 0.02 & 0.09 & [6] \\
\hline 5 & $\mathrm{CH}_{2}$ & $\mathrm{Ph}$ & $\mathrm{F}$ & 0.46 & 0.53 & -0.07 & [8] \\
\hline 6 & $\mathrm{CH}_{2}$ & $\mathrm{Ph}$ & $\mathrm{Cl}$ & 0.53 & 0.68 & -0.15 & [8] \\
\hline 7 & $\mathrm{CH}_{2}$ & $\mathrm{Ph}$ & OR & 0.20 & $(0.20)$ & 0.00 & [9] \\
\hline 8 & $\mathrm{CH}_{2}$ & $\mathrm{Ph}$ & $t-\mathrm{Bu}$ & $1.1^{\mathrm{a}}$ & 1.05 & 0.05 & a \\
\hline 9 & NR & $\mathrm{Me}$ & $\mathrm{Ph}$ & $0.10-0.24$ & $(0.02)$ & $(-0.08-(-0.22))$ & [30] \\
\hline 10 & NR & $\mathrm{Me}$ & OR & -0.21 & $(0.20)$ & $(-0.41)$ & [31] \\
\hline 11 & $\mathrm{O}$ & $\mathrm{Me}$ & $\mathrm{Ph}$ & 0.16 & $(0.02)$ & $(0.14)$ & [32] \\
\hline 12 & $\mathrm{O}$ & $\mathrm{Me}$ & OR & 0.02 & $(0.20)$ & $(-0.18)$ & [33] \\
\hline 13 & $\Omega$ & $\mathrm{Me}$ & F & 0.37 (gas) & 0.51 & 0.14 & [34] \\
\hline 13 & U & & $\mathrm{F}$ & $>1.4$ (solution) & 0.51 & $>0.9$ & [34] \\
\hline 14 & $S$ & $\mathrm{Me}$ & $\mathrm{Ph}$ & 0.15 & 0.25 & -0.10 & [6] \\
\hline 15 & S & $\mathrm{Me}$ & $\mathrm{F}$ & -0.78 & -0.79 & 0.01 & [35] \\
\hline
\end{tabular}

${ }^{a}$ Lower limit of $\mathrm{Ph}_{\mathrm{ax}} t-\mathrm{Bu}_{\mathrm{eq}}: \mathrm{Ph}_{\mathrm{eq}} t-\mathrm{Bu} \mathrm{ax}=92(7): 8(7)(\mathrm{GED}, 337 \mathrm{~K}$; our unpublished results).

Large deviations from additivity in 1,3-dimethyl-3-isopropoxy-3-silapiperidine (No. 10, Table 3) were assigned to the repulsion of the two unidirectional axially oriented dipoles of the nitrogen lone pair and the highly polar Si-O bond (Figure 4, left), destabilizing the $\mathrm{Me}_{\mathrm{eq}} \mathrm{OR}_{\mathrm{ax}}$ conformer and making the $\mathrm{Me}_{\mathrm{ax}} \mathrm{OR}_{\mathrm{eq}}$ conformer predominant (the ratio was measured as 2:1) [31]. This effect is especially important in Si-alkoxy or Si-hydroxy-3-silapiperidines because of a large dipole moment of the Si-O bond and the higher basicity of nitrogen in $\alpha$-silylamines relative to organic amines [36-38].
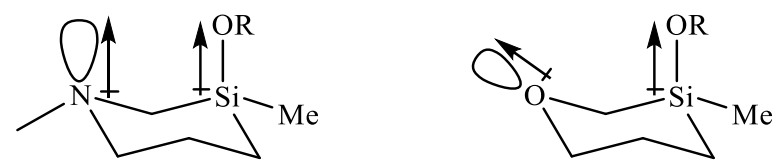

Figure 4. Orientation of the $\mathrm{N}$ and $\mathrm{O}$ lone pairs with respect to the $\mathrm{O}-\mathrm{Si}$ dipole in 1,3-dimethyl-3-isopropoxy-1,3-azasilinane (left) and 3-isopropoxy-3-methyl-1,3-oxasilinane (right).

In 3-isopropoxy-3-methyl-1,3-oxasilinane (No. 12, Table 3), the $\mathrm{Me}_{\mathrm{eq}} \mathrm{OR}_{\mathrm{ax}}: \mathrm{Me}_{\mathrm{ax}} \mathrm{OR}_{\mathrm{eq}}$ ratio is 1:1, so, the deviation from additivity is smaller. The observed shift of the conformational equilibrium toward the $\mathrm{Me}_{\mathrm{eq}} \mathrm{OR}_{\mathrm{ax}}$ conformer is explained by orientation of the oxygen atom lone pair in the C-O-C plane [39], as shown in Figure 4, which reduces the repulsion between the two dipoles, as compared to that in the molecule of 1,3-dimethyl-3-isopropoxy-1,3-azasilinane.

Very recently, we have synthesized 1-methylthio-1-phenyl-1-silacyclohexane and performed its conformational analysis using GED, LT NMR, and quantum chemical calculations [40]. It should be said that this was the first compound of this family that contained the exocyclic sulfur-containing group at silicon. It was prepared in $55 \%$ yield by the replacement of chlorine in 1-chloro-1-phenyl-1-silacyclohexane with MeSNa. The results are summarized in Figure 5.

As follows from Figure 5, all methods clearly show the predominance of $\mathrm{Ph}_{\mathrm{eq}}$ conformer, slightly larger in solution than in gas phase and in nice agreement with theoretical calculations. It must be said that LT NMR spectra were taken not only for ${ }^{1} \mathrm{H}$ and ${ }^{13} \mathrm{C}$ but also for ${ }^{29} \mathrm{Si}$ (Figure 6) [40]. Until 2019, ${ }^{29} \mathrm{Si}$ NMR was not used for conformational analysis of silacyclohexane or any other compounds. The first example was reported in our recent work at the same time (vide infra). 


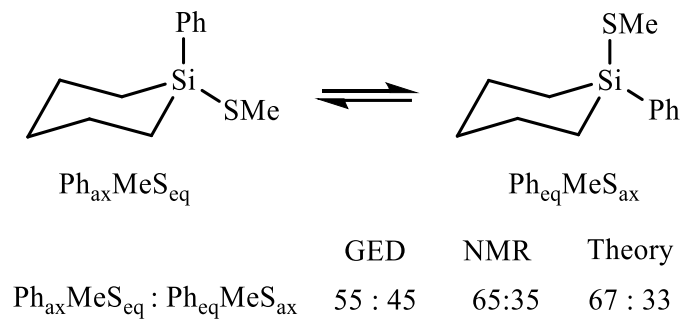

Figure 5. Ratio of 1-methylthio-1-phenyl-1-silacyclohexane conformers by different methods.

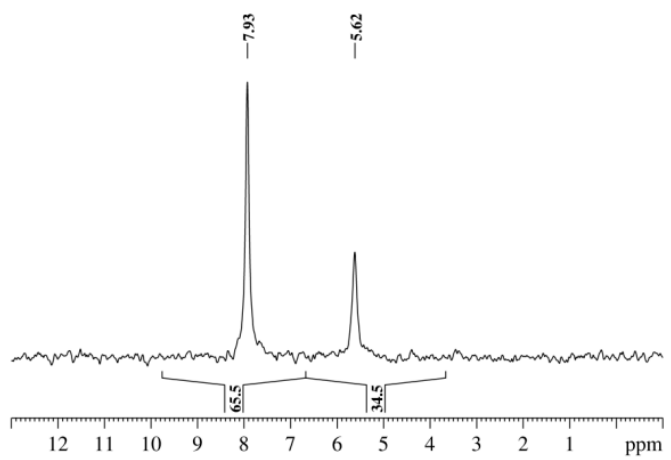

Figure 6. ${ }^{29}$ Si-NMR spectrum of 1-methylthio-1-phenyl-1-silacyclohexane $\mathbf{1}$ at $98 \mathrm{~K}$.

\section{Thiasilacyclohexanes}

The largest family of silaheterocyclohexanes is 3- and 4-silathianes including their S-functional derivatives (Figure 7).

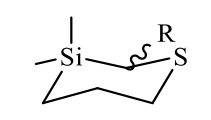

$\mathrm{R}=\mathrm{Me}, \mathrm{Ph}, \mathrm{SiMe}_{3}$

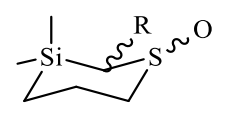

$\mathrm{R}=\mathrm{H}, \mathrm{Me}$

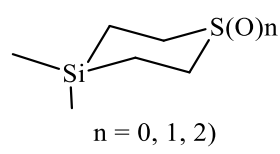

$\mathrm{n}=0,1,2)$
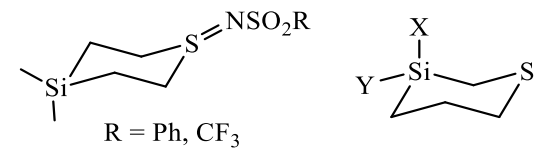

Figure 7. 1,3- and 1,4-thiasilacyclohexanes and their S-functional derivatives.

Smaller conformational energies $A$ are inherent not only to substituents at silicon, but, because of longer $\mathrm{C}-\mathrm{Si}$ and $\mathrm{C}-\mathrm{S}$ bonds, also to the groups attached to the endocyclic carbon atoms. For example, while the value of $A_{\mathrm{Me}}$ is $1.76 \mathrm{kcal} / \mathrm{mol}$ (Table 1), the measured ratio of 2-Me $\mathrm{eq}: 2-\mathrm{Me}_{\mathrm{ax}}$ conformers in the molecule of 2,3,3-trimethyl-3-silathiane is $60: 40$, that corresponds to $\Delta G^{\circ}=0.35 \mathrm{kcal} / \mathrm{mol}$, coinciding with the calculated value of $0.36 \mathrm{kcal} / \mathrm{mol}$ [41]. The analogues of the latter compound with 2- $\mathrm{Me}_{3} \mathrm{Si}$ [41] and 2-Ph substituents [42] exist as single 2-eq conformers due to the large conformational energy of the $\mathrm{Ph}(2.87 \mathrm{kcal} / \mathrm{mol}$, Table 1$)$ and $\mathrm{SiMe}_{3}$ group (experimental $2.5 \mathrm{kcal} / \mathrm{mol}$, [43], theoretical $2.05 \mathrm{kcal} / \mathrm{mol}$ [44].

An interesting effect of the ring silicon atom was found when analyzing 3-silathiane S-oxides. The predominant existence of cyclic sulfoxides in the $\mathrm{SO}_{\mathrm{ax}}$ conformation is well known [45]. Introduction of substituents at the 3-position to sulfur either in thiane or 3-silathiane destabilizes the $\mathrm{SO}_{\mathrm{ax}}$ form, and both 3,3-dimethylthiane 1-oxide [46,47] and 3,3-dimethyl-3-silathiane S-oxide [46] exist in solution completely in the $\mathrm{SO}_{\text {eq }}$ form.

The situation becomes more complicated when another substituent is introduced into the ring. Thus, the molecule of 2,3,3-trimethyl-3-silathiane S-oxide having two chiral centers (atoms C-2 and S), can exist as two diastereomers. Indeed, oxidation of 2,3,3-trimethyl-3-silathiane gives rise to the cis/trans diastereomeric mixture of the corresponding S-oxides in 1:2 ratio. The trans-isomer can adopt only the eq-eq form, but for the cis-isomer the $\mathrm{Me}_{\mathrm{eq}} \mathrm{SO}_{\mathrm{ax}}$ and $\mathrm{Me}_{\mathrm{ax}} \mathrm{SO}_{\mathrm{eq}}$ are in equilibrium (Figure 8) with the ratio $\mathrm{Me}_{\mathrm{eq}} \mathrm{SO}_{\mathrm{ax}}: \mathrm{Me}_{\mathrm{ax}} \mathrm{SO}_{\mathrm{eq}}$ equal to $1: 1$ at room temperature or $5: 1$ at $-120^{\circ} \mathrm{C}$. This is consistent 
with the large $A_{\mathrm{Me}}$ value $(1.76 \mathrm{kcal} / \mathrm{mol})$ and a small negative value of $A_{\mathrm{SO}}(-0.18 \mathrm{kcal} / \mathrm{mol})$. Although the presence of silicon in the ring lowers the $A_{\mathrm{Me}}$ value and makes the $A_{\mathrm{SO}}$ value positive, the $\mathrm{Me}_{\mathrm{eq}} \mathrm{SO}_{\mathrm{ax}}$ conformer is still preferable at low temperatures [48].

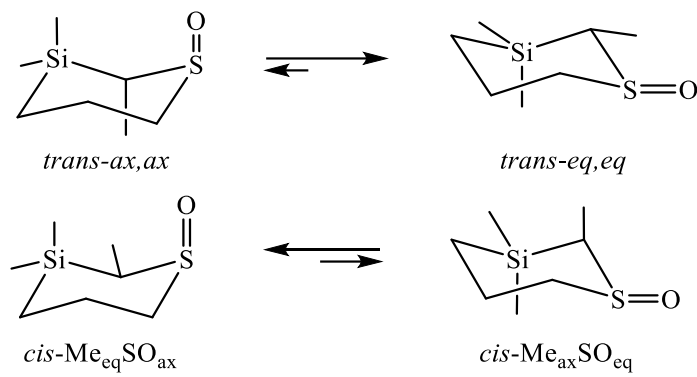

Figure 8. Conformational equilibria in the trans and cis isomers of 3-silathiane S-oxides.

In 4-silathiane S-oxides, the situation is different (Figure 9). The conformational equilibrium in solution is shifted to the equatorial conformer, the $\mathrm{SO}_{\mathrm{eq}}: \mathrm{SO}_{\mathrm{ax}}$ being $63: 37$, which is comparable with the 55:45 ratio found for thiane S-oxide [47].

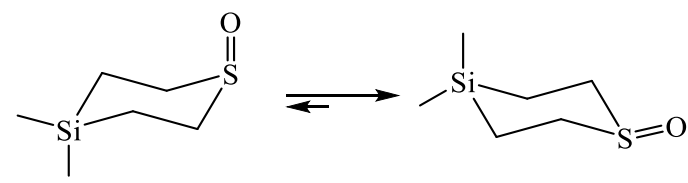

Figure 9. Predominance of the $\mathrm{SO}_{\mathrm{eq}}$ conformer for 4-silathiane S-oxide.

Interestingly, theoretical DFT calculations showed the $\mathrm{SO}_{\mathrm{ax}}$ conformer to be more stable by $0.93 \mathrm{kcal} / \mathrm{mol}$ [49], which seems to contradict the experiment. However, due to a larger dipole moment of $\mathrm{SO}_{\text {eq }}\left(5.41\right.$ vs. $4.21 \mathrm{D}$ in $\mathrm{SO}_{\mathrm{ax}}$ ) the use of the $\mathrm{PCM}$ in $\mathrm{CHCl}_{3}$ as the solvent led to the inversion of the relative stability and the $\mathrm{SO}_{\mathrm{eq}}$ conformer was found to be $0.19 \mathrm{kcal} / \mathrm{mol}$ more stable [49]. This gives the ratio $\mathrm{SO}_{\mathrm{eq}}: \mathrm{SO}_{\mathrm{ax}}$ of 70:30 in excellent agreement with the experiment.

Theoretical studies of 4-silathiane S-oxides posed an interesting question about their molecular structure. Usually, sila(hetero)cyclohexanes adopt chair conformation. However, in the presence of one or two halogen atoms at silicon, the boat conformer may become a local minimum on the potential energy surface due to intramolecular $\mathrm{S}=\mathrm{O} \cdots \mathrm{Si}$ coordination, as shown in Figure 10.

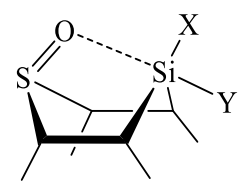

Figure 10. 'Scorpionoid' boat structure of axial 4-silathiane S-oxides bearing halogens at silicon.

For these structures, we coined the term 'scorpionoids', in which the silicon atom resembles the head and the sulfoxide oxygen atom the stinging tail. The relative stability of the chair and boat forms of 4-silathiane S-oxides with one or two halogens at silicon was analyzed in [50] (see also references cited therein). In the pentacoordinate motif around the silicon atom, the $\mathrm{O} \cdots$ Si distance for various pairs of halogens $(\mathrm{X}, \mathrm{Y}=\mathrm{H}, \mathrm{F}, \mathrm{Cl}, \mathrm{Br})$ fall in the range of 2.05-2.15 $\AA$, and is much less than the sum of the vdW radii of the two atoms (3.62 $\AA$ ). Penta-coordination is also confirmed by the close to planar CCX equatorial arrangement around silicon, and by longer axial bond $\mathrm{Si}-\mathrm{Y}$ than the equatorial bond $\mathrm{Si}-\mathrm{X}$ in the bipyramidal silicon coordination knot [50]. We know only one example of the $\mathrm{S}=\mathrm{O} \cdots \mathrm{Si}$ coordination in which the trigonal bipyramidal structure was proved experimentally [51]. 
4-Silathiane S-sulfimides, which are isoelectronic analogues of 4-silathiane S-oxides (Figure 7), also have very low activation barriers from 4.4 to $4.7 \mathrm{kcal} / \mathrm{mol}$ [52]. For N-phenylsulfonyl-4-silathiane S-sulfimide (Figure 7) the conformational equilibrium is almost degenerate (1:1), whereas in $\mathrm{N}$-triflyl-4-silathiane S-sulfimide the equilibrium is shifted to the axial conformer ( $255: 45)$ due to electronegative $\mathrm{CF}_{3}$ group [52]. It should be mentioned, that in addition to the $a x$ and eq conformers of the sulfimide motif, two rotamers, namely, with the "inward" or "outward" $\mathrm{CF}_{3}$ group may exist [53].

It also deserves mentioning that the value of $A_{\mathrm{Me}}$ in 3-methyl-3-silathiane is $0.35 \mathrm{kcal} / \mathrm{mol}$ [35], that is, larger than in the absence of sulfur atom in the ring $(0.23 \mathrm{kcal} / \mathrm{mol}$, Table 1$)$. A detailed analysis allowed us to conclude that the conformational preferences are governed not only by the $A$ values of the substituents at the silicon atom, but the donor-acceptor interactions between the orbitals of the vicinal bonds play the decisive role; the degree of these interactions was evaluated by the use of the NBO analysis [35].

\section{Azasilacyclohexanes (azasilinanes) and Related Compounds}

The structures, for which the conformational analysis was done, are given in Figure 11. The results of this analysis should be compared to those for the structures in Figure 7, to determine the effect of the nature of the heteroatom in the ring, and to the silicon-free analogues, like morpholines and piperidines.<smiles>[R]N1C[Si](C)(C)O[Si](C)(C)C1</smiles>

$\mathrm{R}=\mathrm{Me}, i-\mathrm{Pr}$<smiles>[R]N1CCO[Si](C)(C)C1</smiles>

$\mathrm{R}=\mathrm{Me}, \mathrm{Bn}, \mathrm{Ph}$<smiles>CCCN1C[Si](C)(C)O[Si](C)(C)C1</smiles><smiles>C[Si]1(C)CCN([Al])CC1</smiles><smiles>C[Si]1CN2COCC(CO)(CO1)C2</smiles><smiles>[R]N1CCC[Si]([X])([X])CC1</smiles>

$\mathrm{R}=\mathrm{Me}, i$-Pr $\mathrm{X}=\mathrm{H}, \mathrm{Me} ; \mathrm{Y}=\mathrm{Me}, \mathrm{Ph}, i$-Pr<smiles>[R]N1CC[Si](O)([AlH2])CC1</smiles>

$\mathrm{HO}$

Figure 11. Structurally and conformationally studied azasilacyclohexanes (azasilinanes).

The barriers to ring inversion in 4-alkyl-2,2,6,6-tetramethyl-1,4,2,6-oxaazadisilinanes amount to $8.1 \pm 0.4 \mathrm{kcal} / \mathrm{mol}$ [54], which is less than $11.1 \mathrm{kcal} / \mathrm{mol}$ in $\mathrm{N}$-methylmorpholine without $\alpha$-methyl groups to oxygen $[55,56]$. Again, this is due to the longer $\mathrm{Si}-\mathrm{C}$ than $\mathrm{C}-\mathrm{C}$ bonds and less folded $\mathrm{SiOSi}$ part of the molecule.

The strongly electron acceptor triflyl group at the nitrogen atom makes it planar, but still two rotamers with the 'inward' or 'outward' $\mathrm{CF}_{3}$ group differing in energy by $1.1 \mathrm{kcal} / \mathrm{mol}$ in favor of the latter may exist. According to the $\mathrm{X}$-ray analysis, in the crystal the compound exists as the single 'outward' rotamer [57] (Figure 12).

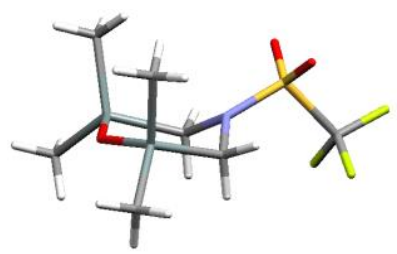

Figure 12. 'Inward' rotamer of 2,2,6,6-tetramethyl-4-triflyl-1,4,2,6-oxazadisilinane.

For N-triflyl-4-silapiperidine, the MP2 calculated $\Delta E$ is $0.6 \mathrm{kcal} / \mathrm{mol}$ in favor of the 'outward' rotamer, corresponding to the ratio of 95:5. The $\mathrm{LT}^{13} \mathrm{C}-\mathrm{NMR}$ spectroscopy showed the presence of two conformers in the ratio 98:2, which excellently coincides with calculations [57]. 
The experimental barriers to ring inversion in the N-triflyl compounds in Figure 11 are $12.9 \pm 0.2 \mathrm{kcal} / \mathrm{mol}$. An intriguing question is why the barriers in the molecules with almost planar nitrogen are higher than in non-planar $\mathrm{N}$-alkyl derivatives? The answer is that these barriers refer to the interconversion between the outward and inward rotamers, rather than to the ring inversion. Since the total reaction rate cannot be larger than the rate of its limiting step, the overall barrier must be equal to that for the slowest step of the process. The conversion of rotamers of $\mathrm{N}$-triflyl heterocycles is characterized by the barriers of $12-14 \mathrm{kcal} / \mathrm{mol}$ [58-60].

The crystal structure of a series of N-arylated N-hydroxy-1,3-azasilinanes (4-aryl-4-hydroxy-4 -silapiperidines) was determined by Tacke et al. who reached the conclusion that the energy difference between the isomers of silapiperidines is notably smaller than in the corresponding piperidines [61-65]. In 1,4,2-oxaazasilinanes with different substituents at nitrogen in Figure 11, the ring inversion barriers decrease in the order $8.85(\mathrm{R}=\mathrm{Me})>7.7(\mathrm{R}=\mathrm{Bn})>4.8(\mathrm{R}=\mathrm{Ph}) \mathrm{kcal} / \mathrm{mol}$ [66], that means, with increased conjugation of $\mathrm{N}_{\mathrm{LP}}$ with $\mathrm{R}$. Their quaternization by MeI allowed to prepare the corresponding salts and to investigate them by LT NMR; for the N,N-dimethyl salt, the degenerate conformational equilibrium is too fast even at $103 \mathrm{~K}$, but for the Me,Bn-salt it was frozen and the barrier of interconversion of the conformers equal to $6.1 \mathrm{kcal} / \mathrm{mol}$ and the conformational ratio $\mathrm{Me}_{\mathrm{ax}} \mathrm{Bn}_{\mathrm{eq}}: \mathrm{Me}_{\mathrm{eq}} \mathrm{Bn}_{\mathrm{ax}}=60: 40$ were found [66].

In solution, the simplest representative of 1,3-dimethyl-1,3-azasilinanes ( $X=H, Y=R=M e)$ gives an equilibrium mixture SiMe $\mathrm{ax}_{\mathrm{a}} \mathrm{SiMe}$ eq $=1: 2$ (33:67 or 30:70 from ${ }^{1} \mathrm{H}$ - or ${ }^{13} \mathrm{C}$ - LT NMR) [65]. However, in gas phase the axial conformer predominates and the ratio inverts to 2:1 [66]. This corresponds to the Gibbs free energy difference of $-0.21 \mathrm{kcal} / \mathrm{mol}$, which is lower than in 1,3-dimethylpiperidine $(-1.6 \mathrm{kcal} / \mathrm{mol}$ [67]) but almost equal to that in 1-methyl-1-silacyclohexane $(-0.23 \mathrm{kcal} / \mathrm{mol}$ [5]). Thus, the influence of the nitrogen atom on the barrier to ring inversion in 1,3-dimethylpiperidine (1.60 versus $1.76 \mathrm{kcal} / \mathrm{mol}$ in methylcyclohexane) is low $(\sim 10 \%)$ but measurable, while in silaheterocyclohexanes it is practically zero $(0.02 \mathrm{kcal} / \mathrm{mol})$.

1,3,3-Trimethyl-1,3-azasilinane was the first $\mathrm{Si}, \mathrm{N}$-heterocycle for which the gas phase structure was obtained [68]. The angle of folding between the $\mathrm{C} 2 \mathrm{Si3C} 4$ plane and the N1C2C4C5 plane was found to be $\sim 40^{\circ}$ and the angle between the $\mathrm{C} 6 \mathrm{~N} 1 \mathrm{C} 2$ and $\mathrm{C} 2 \mathrm{Si3C} 5 \mathrm{C} 6$ planes $-\sim 60^{\circ}$.

For the Si-chiral 1,3-azasilinanes in Figure $11(\mathrm{X}=\mathrm{Me}, \mathrm{Y}=\mathrm{Ph}, \mathrm{R}=\mathrm{Me}$ or $i$-Pr), the equilibrium is not degenerate, and the conformer ratio was measured as 67:33 $(\mathrm{R}=\mathrm{Me})$ [30] or 58.5:41.5 $(\mathrm{R}=i$-Pr) [69], in both cases in favor of the $\mathrm{Ph}_{\mathrm{eq}}, \mathrm{Me}_{\mathrm{ax}}$ conformers. The ring inversion barriers were determined to be equal to $9.0 \mathrm{kcal} / \mathrm{mol}$ for $\mathrm{R}=\mathrm{Me}$ [30] or $8.25 \mathrm{kcal} / \mathrm{mol}$ for $\mathrm{R}=i-\operatorname{Pr}[69]$.

Among the investigated $\mathrm{Si}, \mathrm{N}, \mathrm{O}-$ heterocycles, an interesting object was the silicon analogue of quinolizidine, (3,3,7,7-tetramethylhexahydro- $1 H$-[1.4.2] oxazasilino[4,5-d][1.4.2]oxaazasilin-9a-yl)-methanol, which was prepared by the reaction of aminoalcohol $\mathrm{H}_{2} \mathrm{NC}\left(\mathrm{CH}_{2} \mathrm{OH}\right)_{3}$ with (chloromethyl)(methoxy)dimethylsilane [70] (Figure 13).

$$
\mathrm{H}_{2} \mathrm{NC}\left(\mathrm{CH}_{2} \mathrm{OH}\right)_{3}+2 \mathrm{ClCH}_{2} \mathrm{SiMe}_{2} \mathrm{OMe} \underset{\text { benzene, } \mathrm{rt},}{\stackrel{\mathrm{DBU}}{\longrightarrow}}
$$

Figure 13. Synthesis of (3,3,7,7-tetramethylhexahydro-1H-[1.4.2]oxazasilino[4,5- $d]$ [1.4.2]oxaazasilin-9a-yl) -methanol by condensation/cyclization of 2-amino-2-(hydroxymethyl)propane-1,3-diol with $\mathrm{ClCH}_{2} \mathrm{SiMe}_{2} \mathrm{OMe}$.

X-Ray analysis proved the trans, trans-fused structure in the crystal (Figure 14), but the molecule was conformationally flexible and the barrier for interconversion of the conformers was only $5.8 \mathrm{kcal} / \mathrm{mol}$ [70]. 


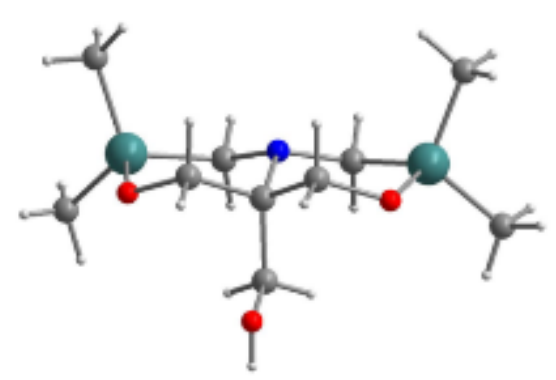

Figure 14. X-ray structure of 3,3,7,7-tetramethylhexahydro-1H-[1.4.2]oxazasilino[4,5- $d][1.4 .2]$ oxaaza-silin-9a -yl)methanol.

Such a flexibility might be suggestive of the cis-fused structure of the two rings in solution, because in decalin the ring inversion is possible only in the cis-isomer, whereas the structure of the trans isomer is rigid. This seeming discrepancy can be rationalized by the fact that in N-fused compounds, such as quinolizidine, inversion at nitrogen atom is possible, as shown in Figure 15.
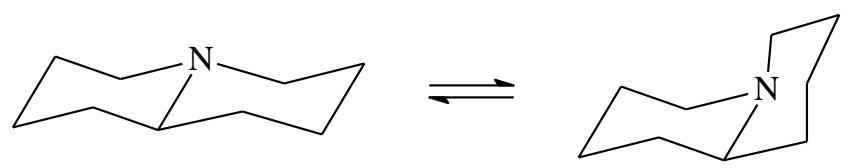

Figure 15. Conformational flexibility of 3,3,7,7-tetramethylhexahydro-1H-[1.4.2] oxazasilino[4,5- $d]$ [1.4.2] oxaazasilin-9a-yl)methanol due to nitrogen pyramid inversion.

Quaternization of the nitrogen atom prevents N-inversion and the isomeric ammonium salts do not suffer interconversion. When treated with methyl iodide, 9a-R-substituted quinolizidines almpost quantitatively give the corresponding salts (Figure 16) existing as the cis/trans isomeric mixtures, in which the molar fraction of the trans isomer decreases in the following order: $\mathrm{H}>\mathrm{CN}>\mathrm{CH}_{3}>\mathrm{CH}_{2} \mathrm{OH}$ $>\mathrm{CH}_{2} \mathrm{NO}_{2}$ [70].

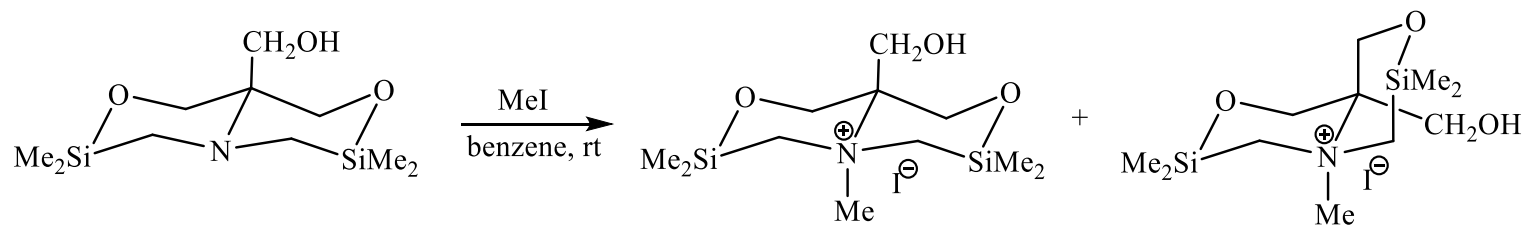

Figure 16. Isomeric salts formed upon quaternization of 3,3,7,7-tetramethylhexahydro -1H-[1.4.2]oxazasilino[4,5- $d][1.4 .2]$ oxaazasilin-9a-yl)methanol.

\section{Oxasilacyclohexanes (Silatetrahydropyrans)}

Some oxygen-containing silacyclohexanes with the endocyclic oxygen as the second heteroatom in the ring (3-silatetrahydropyrans) have been considered above (see Figure 4 and [32-34]. They include disubstituted at silicon compounds with (Me, F), (Me, OPr-i) and (Me, Ph) pairs of substituents. The simplest Si-chiral compound of this series, 3-methyl-3-silatetrahydropyran, was synthesized by the base-catalyzed cyclization followed by dephenylation and reduction [71] as shown in Figure 17. The problem was that it is the most volatile compound as compared to other analogues having boiling point of $62{ }^{\circ} \mathrm{C}$ at $104 \mathrm{~mm} \mathrm{Hg}$ and is easily lost with the solvent during isolation.

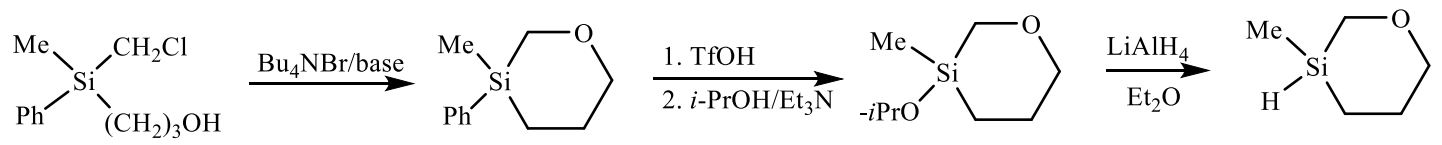

Figure 17. Synthesis of 3-methyl-3-silatetrahydropyran. 
In freons mixture solution at $103 \mathrm{~K},{ }^{13} \mathrm{C}-\mathrm{NMR}$ showed decoalescence of the SiMe, C4 and C5 signals and allowed to measure the conformational ratio and the ring interconversion barrier. As expected, due to small conformational energy $A_{\mathrm{Si}}(\mathrm{Me})$ of $0.23 \mathrm{kcal} / \mathrm{mol}$ the $\mathrm{Me}_{\mathrm{ax}}: \mathrm{Me}_{\mathrm{eq}}$ ratio was 35:65. The activation barrier was very small, $4.6 \mathrm{kcal} / \mathrm{mol}$ [71]. In gas phase the $\mathrm{Me}_{\mathrm{ax}}$ conformer slightly predominates (54:46). The low energy difference between the conformers was in agreement with the theoretically calculated by most of the used DFT and MP2 methods [71].

The Si-phenyl analogue of the above compound, 3-phenyl-3-silatetrahydropyran, and the corresponding silanol, 3-hydroxy-3-phenyl-3-silatetrahydropyran, have been studied by ${ }^{13} \mathrm{C}$ LT NMR and theoretical calculations. Both compounds were synthesized by partial dephenylation from 3,3-diphenyl-3-silatetrahydropyran, as shown in Scheme 1 [72].

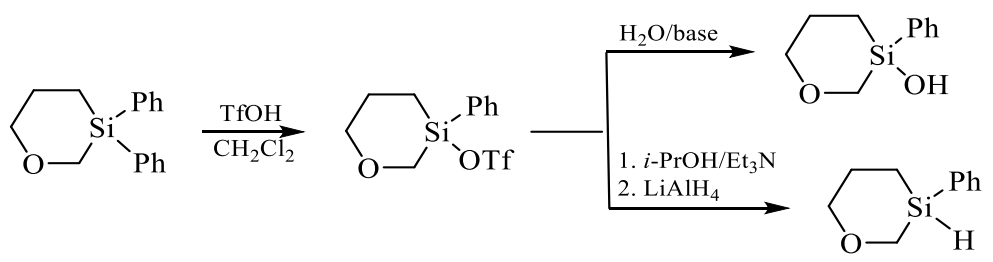

Scheme 1. Synthesis of 3-phenyl-3-silatetrahydropyran and 3-hydroxy-3-phenyl-3-sila-tetrahydropyran.

Unfortunately, no decoalescence of the ${ }^{13} \mathrm{C}$ signals was reached for 3-hydroxy-3 -phenyl-3-silatetrahydropyran at the lowest temperature, so, the conformational equilibrium could not be measured experimentally. There could be because of too low coalescence temperature $(<100 \mathrm{~K})$ or completely one-sided conformational equilibrium. From our experience, both reasons are hardly probable, so the only feasible reason seems to be a small $\Delta \delta\left({ }^{13} \mathrm{C}\right)$ between the conformers. For 3-phenyl-3-silatetrahydropyran, however, the equilibrium was frozen and the ratio $\mathrm{Ph}_{\mathrm{ax}}: \mathrm{Ph}_{\mathrm{eq}}$ was measured as 17.1:82.9, corresponding to $K=4.59$ and $\Delta G^{\circ}=-0.31 \mathrm{kcal} / \mathrm{mol}$ [72].

\section{Si-X-silacyclohexanes $(X=\mathrm{Hlg}, \mathrm{CN}, \mathrm{OMe})$}

Si-Halogenated silacyclohexanes were conformationally studied by I. Arnason et al. (Hlg = F [10], $\mathrm{Cl}, \mathrm{Br}$, I [73]). The results are compiled in Table 4. For comparison, the recently published data for 1-cyano- [74] and 1-methoxy-1-silacyclohexane [75] as well as disubstituted silacyclohexanes with the phenyl group and $\mathrm{Hlg}=\mathrm{F}, \mathrm{Cl}$ [76] or other electronegative groups at silicon are included. Note, that 1-bromo-1-phenylsilacyclohexane has also been synthesized [77] but, because of low stability, its conformational analysis could not be performed.

Table 4. Conformational preferences of Si-halogenated silacyclohexanes $\left(\mathrm{CH}_{2}\right)_{5} \mathrm{Si}(\mathrm{R}, \mathrm{Hlg})$.

\begin{tabular}{ccccc}
\hline \multirow{2}{*}{$\mathbf{R}$} & $\mathbf{X}$ & \multicolumn{3}{c}{$\mathbf{X}_{a x}$ Conformer } \\
\cline { 3 - 4 } & & Gas & Solution & Ref. \\
\hline $\mathrm{H}$ & $\mathrm{F}$ & 63.0 & 64.2 & {$[10]$} \\
& $\mathrm{Cl}$ & 62.5 & 83.0 & {$[73]$} \\
& $\mathrm{Br}$ & 70.5 & 85.7 & {$[73]$} \\
$\mathrm{I}$ & 54.0 & 85.7 & {$[73]$} \\
& $\mathrm{CN}$ & 84 & 35 & {$[74]$} \\
& $\mathrm{OMe}$ & 59 & $-{ }^{*}$ & {$[75]$} \\
$\mathrm{Ph}$ & $\mathrm{F}$ & 40 & 86 & {$[76]$} \\
& $\mathrm{Cl}$ & 79 & 82 & {$[76]$} \\
\hline
\end{tabular}

${ }^{*}$ No decoalescence in NMR. Slight predominance of the ax conformer according to Raman spectroscopy.

As follows from Table 4, for $\mathrm{R}=\mathrm{H}$, all electronegative substituents prefer axial locations in the gas phase, the prevalence of the ax conformer varying from 54 to $84 \%$. For $\mathrm{X}=\mathrm{Hlg}$, the same is true in solution; for $\mathrm{X}=\mathrm{OMe}$, no decoalescence was observed in the NMR spectra, but low-temperature 
Raman spectroscopy also suggested slight predominance of the ax conformer. An interesting exception is strong predominance of $\mathrm{CN}_{\mathrm{eq}}$ in solution, that is, practically the same as in its carbon predecessor, cyanocyclohexane $\mathrm{C}_{5} \mathrm{H}_{11} \mathrm{CN}$, exists predominantly (37:63\%) as proved by GED in gas and by dynamic NMR in solution [78]. The dramatically different conformational behavior of 1-cyano-1-silacyclohexane in solution was assigned by the authors to a strong solvation effect. The conclusion was made based on the NBO analysis that the equatorial conformer is favored by the conjugation and steric effects rather than electrostatic effect. However, steric effect of the cyano group is negligible, so it was reasonably concluded that studying of Si-CN containing compounds "remains a challenging mystery" and deserve further investigation.

For $\mathrm{R}=\mathrm{Ph}$, predominance of conformer $\mathrm{Ph}_{\mathrm{eq}} \mathrm{Cl}_{\mathrm{ax}}$ in all phases and of $\mathrm{Ph}_{\mathrm{eq}} \mathrm{F}_{\mathrm{ax}}$ in solution is in agreement with equatorial preference of the more bulky phenyl group and axial preference of more electronegative halogen atom. In light of this, the predominance of $\mathrm{Ph}_{\mathrm{ax}} \mathrm{F}_{\mathrm{ax}}$, though small, is puzzling. To rationalize the observed conformational ratios, the energy partitioning analysis was employed [76].

\section{Solution vs. Gas Conformational Preferences in Miscellaneous Silacyclohexanes}

As stated above, silacyclohexanes may show inversion of conformational preferences in going from gas to solution, which is not observed for their carbon predecessors. One of the first examples was 1,3-dimethyl-1,3-azasilinane existing predominantly as $\mathrm{SiMe}_{\mathrm{eq}}$ conformer (2:1) in solution but as $\mathrm{SiMe}_{\mathrm{ax}}$ (with the same predominance) in gas phase [66]. Replacement of nitrogen atom in the ring by oxygen (in 3-methyl-3-silatetrahydropyran [71]) or by sulfur (in 3-methyl-3-silathiane [35,79]) does change this trend - in all these heterocyclohexanes the conformational preference is inverted in going from gas to solution. Note, that in the absence of heteroatom, the $\mathrm{Me}_{\mathrm{eq}}$ conformer predominates in both aggregate states [5]. Similar conformational behavior was found for 1-phenylsilacyclohexane, for which strong preference of $\mathrm{Ph}_{\mathrm{eq}}$ conformer was found in solution (78\%) [6] and somewhat less predominance was measured in gas phase $(62 \pm 10 \%)$ [80].

1-Methyl-1-phenyl-1-silacyclohexane containing both methyl and phenyl substituents at silicon was studied first by low-temperature NMR in solution and showed the $\mathrm{Ph}_{\mathrm{eq}} \mathrm{Me}_{\mathrm{ax}}: \mathrm{Ph}_{\mathrm{ax}} \mathrm{Me}_{\mathrm{eq}}$ ratio of 63:37\% at $103 \mathrm{~K}$ [6]. In gas phase, the ratio inverted being $(42 \pm 15):(58 \pm 15) \%$. Therefore, the analysis of conformational preferences in this and related compounds allows to conclude that in gas phase at room temperature, the methyl group in the $\mathrm{Me} / \mathrm{Ph}$ geminally substituted compounds shifts the conformational equilibrium towards the $\mathrm{Ph}_{\mathrm{ax}}$ conformers, from $\mathrm{Ph}_{\mathrm{eq}}: \mathrm{Ph}_{\mathrm{ax}}=100: 0$ in phenylcyclohexane [7] to 28:72 in 1-methyl-1-phenylcyclohexane [19] and from 62:38 in 1-phenylsilacyclohexane [80] to 42:58 in 1-methyl-1-phenyl-1-silacyclohexane [81]. Introduction of oxygen atom into the latter molecule gives 3-methyl-3-phenyl-3-silatetrahydropyran and increases the $\mathrm{Ph}_{\mathrm{ax}} / \mathrm{Ph}_{\text {eq }}$ ratio in the gas phase from 1.38 to 1.63 , which was assigned to $\mathrm{H}_{\text {ortho }} \cdots \mathrm{O}$ interaction in the $\mathrm{Ph}_{\mathrm{ax}}$ conformer, similar to that in 3-phenyltetrahydropyran [82] (Figure 18).
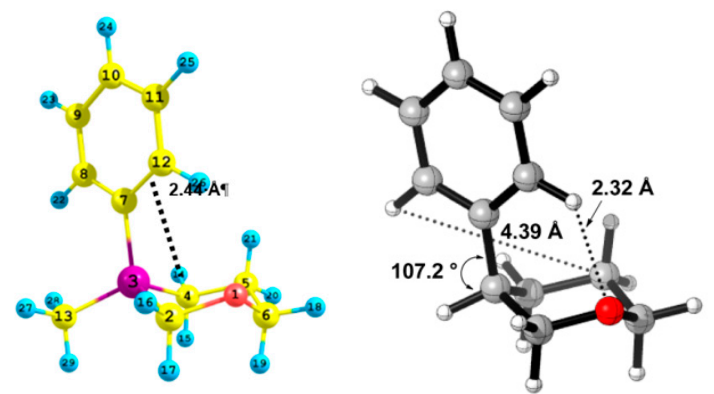

Figure 18. Structure of 3-methyl-3-phenyl-3-silatetrahydropyran [32] (left) and 3-phenyltetrahydropyran [82] (right).

This assumption is in agreement with the change of the conformer ratio of 1-methyl-1-phenyl -1-silacyclohexane in solution in favor of the $\mathrm{Ph}_{\mathrm{eq}}$ conformer because the oxygen lone electron pair in 
solution is involved in $\mathrm{H}$-bonding with more acidic protons of the solvent $\left(\mathrm{CHCl}_{3}, \mathrm{CH}_{2} \mathrm{Cl}_{2}\right.$, freons); weak specific interaction $\mathrm{H}_{\text {ortho }} \cdots \mathrm{O}$ does not play any role and the prevalence of the $\mathrm{Ph}_{\mathrm{eq}}$ conformer is determined by somewhat larger conformational energy $A$ of Ph relative to Me.

Our recent studies [72], [83] on 1-hydroxy-1-phenyl- and 1-methoxy-1-phenylsilacyclohexane, synthesized as described in [84], allow one to compare the gas vs. solution conformational preference of these compounds. Unfortunately, no decoalescence of the ${ }^{13} \mathrm{C}$ signals could be reached for 1-hydroxy-1-phenylsilacyclohexane in solution, but for 1-methoxy-1-phenylsilacyclohexane a significant predominance of the $\mathrm{Ph}_{\mathrm{eq}}$ conformer $\left(\mathrm{Ph}_{\mathrm{ax}}: \mathrm{Ph}_{\mathrm{eq}}=31.2: 68.8\right)$ was measured at $103 \mathrm{~K}$ [72]. In gas phase, close to equimolar ratio $(\sim 50: 50)$ of the two conformers for 1-hydroxy-1-phenylsilacyclohexane and a strong predominance of the $\mathrm{Ph}_{\mathrm{ax}}$ conformer for 1-methoxy-1-phenylsilacyclohexane $\left(\mathrm{Ph}_{\mathrm{ax}}: \mathrm{Ph}_{\mathrm{ax}}=70: 30\right)$ were measured by GED [83]. While the predominance of $\mathrm{Ph}_{\mathrm{eq}}$ in solution is anticipated being in compliance with all rules governing the conformational preferences, the gas phase measurements are unexpected and extremely surprising. Both axial preference of more electronegative $\mathrm{OH}$ or $\mathrm{OMe}$ group and steric effects are in favor of the $\mathrm{Ph}_{\mathrm{eq}}$ conformer in both compounds. However, if to consider the relative polarities of the $\mathrm{C}-\mathrm{Ph}$ and $\mathrm{C}-\mathrm{O}$ bonds by comparing charge differences $\Delta q=$ $q \mathrm{Si}-q \mathrm{C}_{\mathrm{ipso}}$, it turns out that $\Delta \Delta q=\Delta q\left(\mathrm{Ph}_{\mathrm{ax}}\right)-\Delta q\left(\mathrm{Ph}_{\mathrm{eq}}\right)$ only slightly $(<0.01 e)$ varies in all used methods [83]. In contrast, the polarity of the $\mathrm{Si}-\mathrm{O}$ bonds calculated as $\Delta q=q \mathrm{Si}-q \mathrm{O}$ is more sensitive to the location of the $\mathrm{OH}$ or OMe group, and the value of $\Delta \Delta q$ reaches $>0.07 \mathrm{e}$. A general trend is that in both compounds the $\mathrm{Si}-\mathrm{O}$ bond is more polarized in the $\mathrm{Ph}_{\mathrm{eq}}$ than in the $\mathrm{Ph}_{\mathrm{ax}}$ conformer. Also, in 1-methoxy-1-phenylsilacyclohexane, the $\mathrm{Si}-\mathrm{O}$ bond is more polarized than in the corresponding conformers of 1-hydroxy-1-phenylsilacyclohexane. To resolve the contradiction stemming from the axial preference for more electronegative $\mathrm{OH}$ or $\mathrm{OMe}$ group, we assumed that steric factors outweigh small difference in the electronic effects in the molecules under investigation [83]. Sterically, the OMe group creates more hindrances than $\mathrm{OH}$ group, as is proved by the larger barriers to rotation in 1-methoxy-1-phenylsilacyclohexane $(2.3$ and $1.6 \mathrm{kcal} / \mathrm{mol})$ than in 1-hydroxy-1-phenylsilacyclohexane (1.5 and $0.3 \mathrm{kcal} / \mathrm{mol})$. This may explain the observed $\mathrm{Ph}_{\text {ax }}$ predominance in the former (70:30) over that in the latter case (1:1).

\section{Miscellaneous Silacyclohexanes and Related Compounds}

An interesting type of molecular motion was found in 1-dimethylamino-1-phenyl-silacyclohexane possessing two bulky groups, $\mathrm{Ph}$ and $\mathrm{Me}_{2} \mathrm{~N}$, at silicon. The compound was synthesized in $56 \%$ yield as shown in Scheme 2. The compound is rather unstable and is gradually hydrolyzed with time to siloxane with the rupture of the Si-N bond [84].

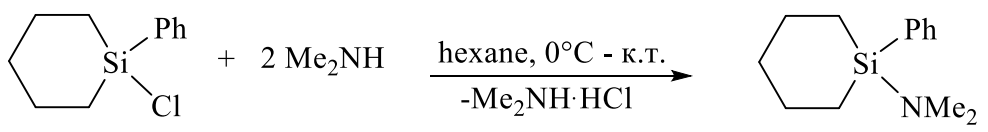

Scheme 2. Synthesis of 1-dimethylamino-1-phenylsilacyclohexane.

The conformational equilibrium of 1-( $\left.\mathrm{Me}_{2} \mathrm{~N}\right)$-1-Ph-1-silacyclohexane was studied by GED, ${ }^{13} \mathrm{C}$ LT NMR and theoretical calculations [85]. The prevalence of $\mathrm{Ph}_{\mathrm{ax}}$ conformer in gas phase $\left(\mathrm{Ph}_{\mathrm{eq}}: \mathrm{Ph}_{\mathrm{ax}}\right.$ $=20: 80 \%)$ is close to that estimated theoretically. In contrast, in solution low temperature ${ }^{13} \mathrm{C}-\mathrm{NMR}$ spectroscopy showed the predominance of the $\mathrm{Ph}_{\mathrm{eq}}$ conformer, $\mathrm{Ph}_{\mathrm{eq}}: \mathrm{Ph}_{\mathrm{ax}}=77: 23$. However, the validity of this conclusion depends on whether the assignment of the signal is correct or not. It should be said, that the predominance of $\mathrm{Ph}_{\mathrm{ax}}$ conformer in the gas phase is in agreement with MP2 but not with DFT calculations. In solution, the assignment of signals in the ${ }^{13} \mathrm{C}$-LT NMR spectra is not unequivocal, either. By comparing with the spectra of 1-Ph and 1-Ph,1-X-silacyclohexanes ( $\mathrm{X}=\mathrm{Me}, \mathrm{OMe}, \mathrm{F}, \mathrm{Cl})$ after decoalescence $[6,72,76]$, all experimental and theoretically calculated chemical shifts, except those for C-1,5 signal, argue for 1-Ph $h_{e q} N_{a x}$ to be the preferred conformer of 1-(dimethylamino)-1-phenylsilacyclohexane. 
The potential energy surface profile for the $\mathrm{Ph}$ and $\mathrm{NMe}_{2}$ group rotation about the $\mathrm{Si}-\mathrm{C}_{\mathrm{Ph}}$ and $\mathrm{Si}-\mathrm{N}$ bonds showed the presence of several conformers. In all of them, because of steric repulsion between the the ortho-protons and methyl hydrogen atoms, the $\mathrm{NMe}_{2}$ group rotation induces rotation of the Ph group, and vice versa. In Figure 19, the corresponding correlation plots are shown for the $\mathrm{Ph}_{\mathrm{ax}}$ and $\mathrm{Ph}_{\mathrm{eq}}$ conformers. As is clearly seen, rotation of the two groups is strongly correlated, which is typical for gear motion in molecular motors. 'Vertical' lines in the left picture appear because for two scanned angles of the $\mathrm{NMe}_{2}$ group differing by $5^{\circ}$ the geometry optimization of the axial Ph group leads the system to two different local minima, causing a 'jump' of energy [85].

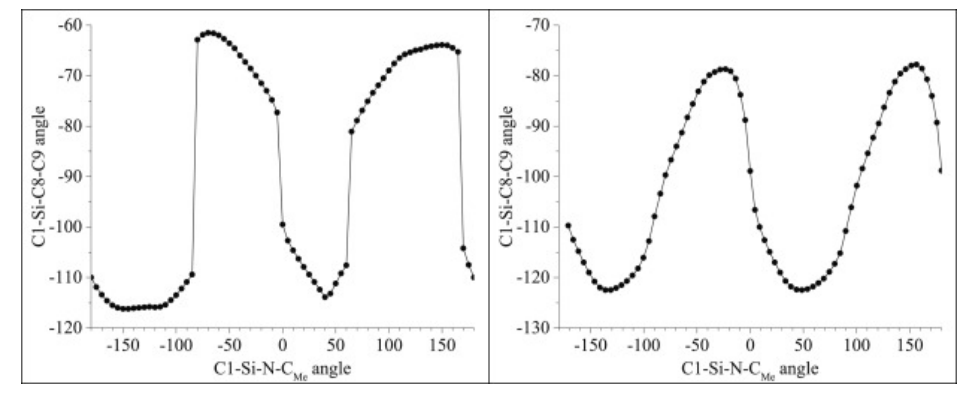

Figure 19. Correlation between dihedral angles $\mathrm{C} 1-\mathrm{Si}-\mathrm{C}_{\mathrm{ipso}}-\mathrm{C}_{\text {ortho }}$ and $\mathrm{C} 4-\mathrm{Si}-\mathrm{N}-\mathrm{Me}$ in the $\mathrm{Ph}_{\mathrm{ax}}$ (left) and $\mathrm{Ph}_{\mathrm{eq}}$ conformers (right) of 1-(dimethylamino)-1-phenylsilacyclohexane.

Due to the aforementioned subordinate role of steric effects in silacyclohexanes, $\mathrm{Ph}_{\mathrm{eq}}$ conformers predominate in nearly all studied 1-phenylsila(hetero)cyclohexanes [6,71]. The only exception was our recent study revealing the predominance of $\mathrm{Ph}_{\mathrm{ax}}$ in 1-hydroxy-1-phenylsilacyclohexane [72]. Despite a progress in the conformational analysis of the sila(hetero)cyclohexanes having the Ph group at silicon, the question of the possibility of their existence as $\mathrm{Ph}_{\mathrm{ax}}$ conformers has remained open. To fill this gap, we investigated (1,1'-phenyl-1,1'-silacyclohex-1-yl)-disiloxane. The target compound was synthesized by hydrolysis of 1-chloro-1-phenylsilacyclohexane and its ${ }^{13}$ C-LT NMR spectra were registered [86]. Possible conformers are shown in Figure 20.

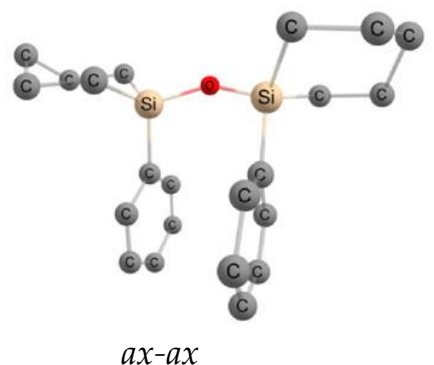

$a x-a x$

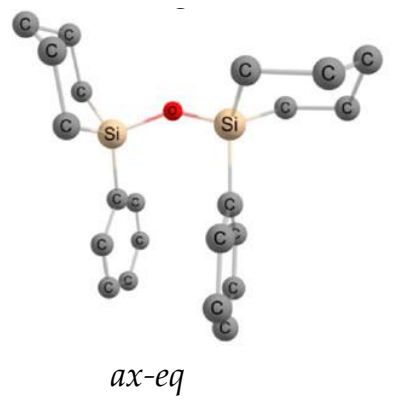

$a x-e q$

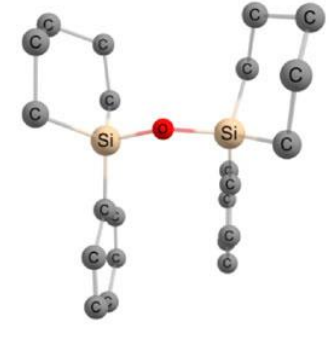

$e q-e q$

Figure 20. Optimized geometry $\left(\mathrm{M} 062 \mathrm{X} / 6-311 \mathrm{G}^{* *}\right)$ of possible conformers of $\left(1,1^{\prime}\right.$-phenyl-1, $1^{\prime}$ -silacyclohex-1-yl)-disiloxane. ' $a x^{\prime}$ and ' $e q$ ' refer to the position of the phenyl group.

Theoretical conformational analysis showed a slight energetic preference of the $\mathrm{Ph}_{\mathrm{ax}}$ conformers $\left(\mathrm{Ph}_{\mathrm{ax}}, \mathrm{Ph}_{\mathrm{ax}}>\mathrm{Ph}_{\mathrm{ax}}, \mathrm{Ph}_{\mathrm{eq}}>\mathrm{Ph}_{\mathrm{eq}}, \mathrm{Ph}_{\mathrm{eq}}\right)$ in spite of higher $A$ values for the bulkier phenyl group. This was explained by a larger energy gain from shortening of the $\mathrm{Si}-\mathrm{O}$ bonds in the $\mathrm{Ph}_{\mathrm{ax}}$ conformers, which outweighed steric destabilization. Unfortunately, low-temperature ${ }^{1} \mathrm{H}$ or ${ }^{13} \mathrm{C} \mathrm{NMR}$ studies showed the conversion of the conformers to be still fast on the NMR timescale at $100 \mathrm{~K}$, so, further quantification could not be accomplished.

The answer to the question of conformational equilibrium of the studied siloxane was obtained from the ${ }^{29} \mathrm{Si}$-LT NMR spectra, which contained the signals of all three conformers [87]. This allowed to determine the ratio of the conformers and to assign them in accordance with the relative stability using the theoretically calculated ${ }^{29} \mathrm{Si}$ chemical shifts at the 
GIAO/B3LYP/6-311++G(d,p)//B3LYP/6-311++G(d,p) level. The calculated shifts are reliable because (i) they lie in the interval of $2.3 \mathrm{ppm}$, which is well consistent with the experiment (2.6 ppm); (ii) the highest signal in the spectrum in Figure 21 is the most upfield one; the calculated signal for the most stable and, hence, most abundant $a x$-ax conformer also lies the most high field; (iii) the signal of lowest intensity is the most downfield one (Figure 21) and corresponds to the least stable eq-eq conformer; (iv) two signals of equal intensity appear between them and, judged from the relative energies of conformers in Figure 19, belong to the ax-eq conformer.

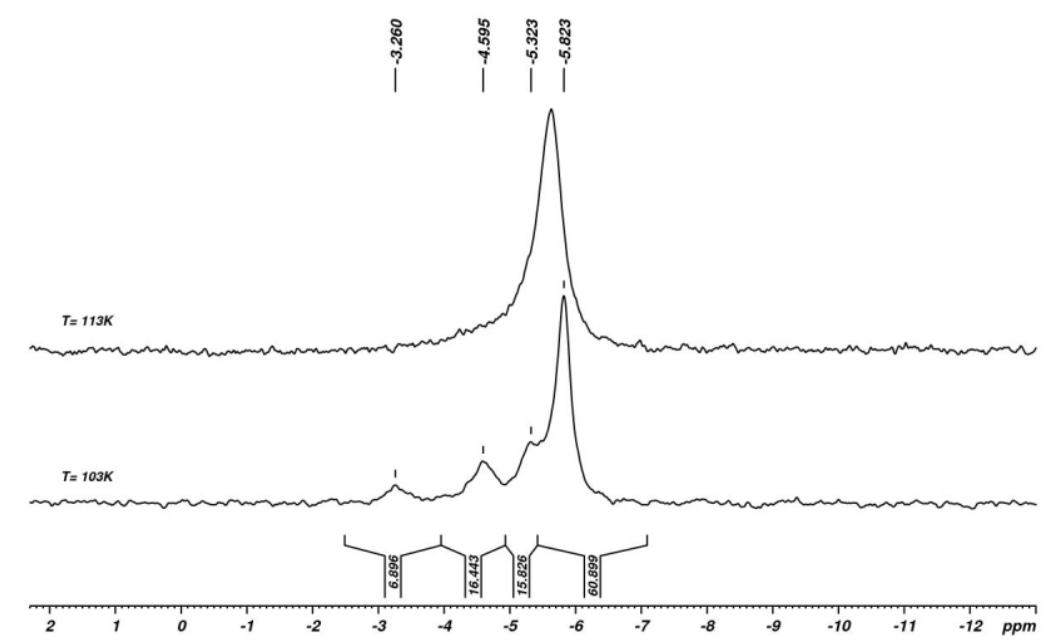

Figure 21. ${ }^{29} \mathrm{Si}-\mathrm{NMR}$ spectra of $\left(1,1^{\prime}\right.$-phenyl-1,1'-silacyclohex-1-yl)disiloxane at $113 \mathrm{~K}$ (above) and at $103 \mathrm{~K}$ (below).

The ring inversion barrier $\Delta G^{\#}$ measured from the temperature of decoalescence $T_{\mathrm{c}}$ and the value of $\Delta \delta$ of the $a x-a x$ and $e q-e q$ conformers was found to be one of the lowest ever measured for six-membered rings, $4.8 \mathrm{kcal} / \mathrm{mol}$ [87].

It deserves to be mentioned that the spectrum in Figure 21 represents the first example of application of the low temperature ${ }^{29} \mathrm{Si}-\mathrm{NMR}$ spectroscopy in conformational analysis [87] (cf. also Figure 6 and the text above).

Interesting analogues of sila(hetero)cyclohexanes are sila(hetero)cyclohexenes. The first sulfur-containing silacyclohexene, 4,4-dimethyl-3,4-dihydro-2H-1,4-thiasiline, was obtained as shown in Scheme 3, in $66 \%$ yield by the rearrangement of 4,4-dimethyl-1,4-thiasilinane 1-oxide, using trifluoroacetic anhydride $\left(\mathrm{R}=\mathrm{CF}_{3}\right)$ [88].

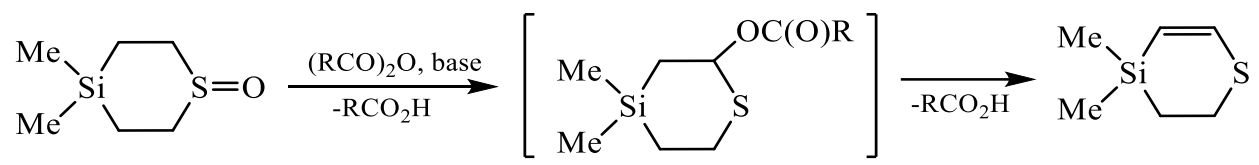

Scheme 3. Pummerer rearrangement of 4,4-dimethyl-1,4-thiasilinane S-oxide

3,4-Dihydro-2H-1,4-thiasilines are interesting heterocycles for conformational analysis, but till our studies there were no information on the conformational preferences even of their monoheteroatomic predecessors-silacyclohexenes or 3,4-dihydro- $2 \mathrm{H}$-thiopyrans-not to mention thiasilacyclohexenes. Moreover, due to different chains linking the silicon and sulfur atoms (Figure 22), the molecule is chiral. However, the conformational equilibrium of the synthesized 4,4-dimethyl-3,4-dihydro-2H-1,4-thiasiline is fast on the NMR timescale even at $103 \mathrm{~K}$, assumingly, due to higher flexibility, by analogy with very flexible cyclohexene ring $\left(\Delta \mathrm{G}^{\neq}=5.37 \mathrm{kcal} / \mathrm{mol}\right.$, [89]) as compared to the cyclohexane ring $\left(\Delta \mathrm{G}^{\neq}=10.3 \mathrm{kcal} / \mathrm{mol}\right.$, [90]). So, we had to limit our study to theoretical computational analysis [91]. 


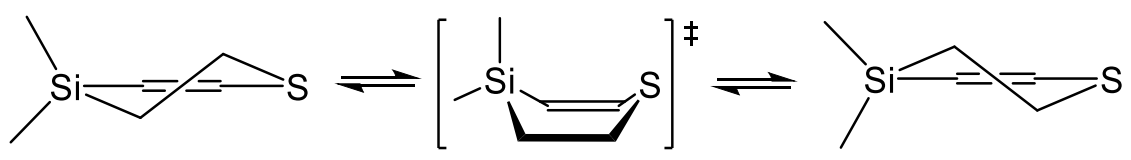

Figure 22. Conformational equilibrium of 4,4-dimethyl-3,4-dihydro-2H-1,4-thiasiline

Calculations, however, did not prove a higher flexibility of the ring in Figure 22. Averaged barrier to the ring interconversion calculated by various methods was $5.7 \mathrm{kcal} / \mathrm{mol}$, that coincides with that calculated by the most precise method MP2/6-311G**//MP2/cc-pVTZ [91].

Presuming that the phenyl groups to silicon would stabilize the compound and increase the barrier of interconversion we have synthesized 4,4-diphenyl-3,4-dihydro-2H-1,4-thiasiline by the same procedure as was used for the 4,4-dimethyl containing analogue [88]. The synthesis, however, was not a simple replica since some transformations were different and required a search for special reaction conditions. Full synthetic scheme, starting from diphenyl(divinyl)silane, is shown in Scheme 4.

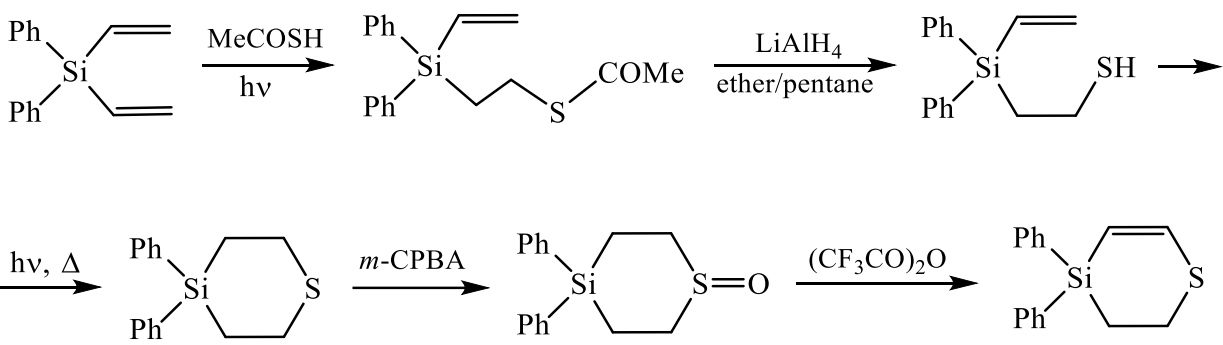

Scheme 4. Synthetic sequence for preparation of 4,4-diphenyl-3,4-dihydro-2H-1,4-thiasiline.

Note, that the synthesized 3,4-dihydro-2H-1,4-thiasilines are the first silicon-containing cyclic vinyl sulfides. Although the target compound, indeed, turned out to be more stable chemically than its dimethylated analogue, still, no decoalescence of the signals in the NMR spectra was reached on cooling.

The higher chemical stability and the presence of sulfur atom in the molecule prompted us to synthesize S-functionalized derivatives of the final compound in Figure 23 [92]. Another reason was very few data available even on linear S-functional derivatives of $\beta$-silylated vinyl sulfides, to say nothing of cyclic ones. The reaction of oxidation with $m$-chloroperbenzoic acid ( $m$-CPBA) gives the corresponding sulfoxide in $52 \%$ isolated yield. Further oxidation to sulfone was performed using a larger excess of the oxidant in up to $60 \%$ yield (Scheme 5). We have also attempted to prepare the corresponding sulfonimide by the reaction with chloramine $\mathrm{B}$. The formation of the target product was proved by the appearance of two new doublets of the $\mathrm{SiCH}=$ and $\mathrm{SCH}=$ protons, different from those in other compounds in Scheme 5, as well as by the presence of two multiplets of diastereotopic $\mathrm{SiCH}_{2}$ protons, as in the case of the related sulfoxide. Since sulfonimides are the least stable among the S-functional derivatives, we failed to isolate the product in the analytically pure form, because the reaction is followed by generation of a large amount of nonidentified polysiloxanes. Nevertheless, the spectral data unequivocally prove its formation.

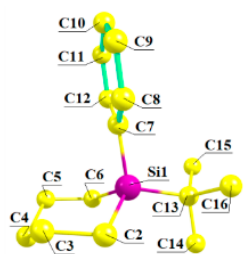

$\mathrm{Ph}_{\mathrm{ax}}$

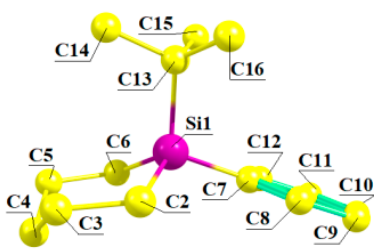

Pheq_90

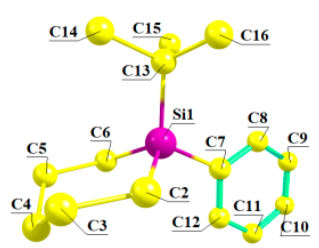

Pheq_0

Figure 23. Total synthesis of 4,4-diphenyl-3,4-dihydro-2H-1,4-thiasiline. 


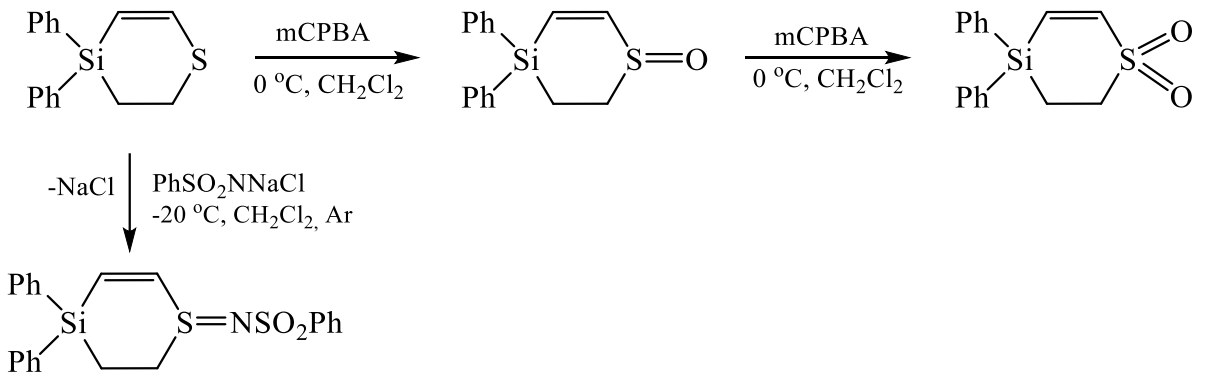

Scheme 5. Synthesis of S-functional derivatives of 4,4-diphenyl-3,4-dihydro-2H-1,4-thiasiline.

Much lower stability of 4,4-dimethyl-3,4-dihydro-2H-1,4-thiasiline is characteristic also for its S-functional derivatives. During oxidation with $m$-CPBA, the compound, usually containing $>10 \%$ of siloxane, gives a mixture of the sulfoxide, sulfone, and open-chain siloxanes containing the sulfoxide or sulfonyl groups [93].

Finally, the last investigated conformationally silacyclohexane was 1-t-butyl-1-phenyl -1-silacyclohexane, containing two voluminous substituents at silicon (our unpublished results). Both $\mathrm{Ph}$ and $t$-Bu groups are anancomeric in cyclohexanes, but in silacyclohexanes, only the $t$-Bu group has the $A$ value large enough to be fully located in the equatorial position (Table 1 ). The synthesis of the target compound was challenging and each stage had to be optimized. After cyclization of $\mathrm{PhSiCl}_{3}$ with the di-magnesium derivative of 1,5-dibromopentane, $\mathrm{BrMg}\left(\mathrm{CH}_{2}\right)_{5} \mathrm{MgBr}$, and subsequent treatment of the formed 1-chloro-1-phenyl-1-silacyclohexane with $t$-BuLi in pentane, the target product was obtained in $43 \%$ yield.

The conformational analysis was performed experimentally by GED and theoretically using DFT and MP2 calculations in gas phase. Three conformers were analyzed, as shown in Figure 23.

From the quantum chemical calculations, the $\mathrm{Ph}_{\mathrm{ax}}$ and $\mathrm{Ph}_{\text {eq_90 }}$ conformations are most stable, the $\Delta G$ value of the $\mathrm{Ph}_{\text {eq_90 }}$ conformer being higher by $1.20-1.91 \mathrm{kcal} / \mathrm{mol}$ (cf. with the difference $A_{\mathrm{t}-\mathrm{Bu}}-A_{\mathrm{Ph}}$ of $1.05 \mathrm{kcal} / \mathrm{mol}$ in Table 1). The calculated molar fraction of the $\mathrm{Ph}_{\mathrm{ax}}$ conformer varies within $88-96 \%$, being in nice agreement with the GED experimentally measured ratio $\mathrm{Ph}_{\mathrm{ax}}: \mathrm{Ph}_{\mathrm{eq}} 90=92(7): 8(7) \%$. It can be concluded, that in the series of 1-Ph-1-X-silacyclohexanes for $\mathrm{X}=\mathrm{H}, \mathrm{CH}_{3}, t-\mathrm{Bu}$, the contribution of the $\mathrm{Ph}_{\mathrm{ax}}$ conformer increases from 38(10) to 58(15) and 92(8)\% with increasing the $\mathrm{X}$ group size.

To summarize, the specific features of the structure and conformational properties of various sila(hetero)cyclohexanes and some of their derivatives are analyzed in comparison to the carbon predecessors and with an accent on the recent studies in the field. In brief, they are: (i) the determining role of electrostatic as well as stereoelectronic effects due to the presence of a highly electropositive silicon atom and strongly polarized Si-X bonds; (ii) subordinate role of steric effects due to large covalent radius of $\mathrm{Si}$; (iii) much lower conformational energies of the substituents at $\mathrm{Si}$; (iv) much lower barriers to ring interconversion due to substantially planarized Si-containing fragment of the ring; (v) strong dependence on the aggregate state, in many cases resulting in the inversion of conformational preferences in going from gas to the solution.

The performed analysis can be useful for studying other heterocycles containing either 'tetrel' elements $(\mathrm{Ge}, \mathrm{Sn}, \mathrm{Pb})$ or the silicon atom neighbors ( $\mathrm{P}, \mathrm{As}, \mathrm{S}$, Se, etc.).

Funding: This research received no external funding.

Acknowledgments: The author is very grateful to his colleagues and coworkers: S.V. Kirpichenko, E.N. Suslova, N.N. Chipanina, L.P. Oznobikhina (Irkutsk Institute of Chemistry, Russia), E. Kleinpeter (Potsdam University, Germany), S.A. Shlykov (Ivanovo State University of Chemistry and Technology, Russia).

Conflicts of Interest: The authors declare no conflicts of interest. 


\section{References}

1. Kleinpeter, E. Conformational Analysis of Saturated Heterocyclic Six-Membered Rings. Adv. Heterocycl. Chem. 2004, 86, 41-127.

2. Shainyan, B.A.; Kleinpeter, E. Silacyclohexanes and silaheterocyclohexanes: Why are they so different from other heterocyclohexanes? Tetrahedron 2013, 69, 5927-5936. [CrossRef]

3. Shainyan, B.A. Structure and conformational analysis of silacyclohexanes and 1,3-silaheterocyclohexanes. Tetrahedron 2016, 72, 5027-5035. [CrossRef]

4. Shainyan, B.A.; Suslova, E.N.; Schilde, U. Crystal structures and theoretical calculations of trans-2,4,4-trimethyl-4-silathiane 1-oxide and 4,4-dimethyl-4-silathiane 1,1-dioxide. Struct. Chem. 2008, 19, 889-894. [CrossRef]

5. Arnason, I.; Kvaran, Á.; Jonsdottir, S.; Gudnason, P.I.; Oberhammer, H. Conformations of Silicon-Containing Rings. 5.' Conformational Properties of 1-Methyl-1-silacyclohexane: Gas Electron Diffraction, Low-Temperature NMR, and Quantum Chemical Calculations. J. Org. Chem. 2002, 67, 3827-3831. [CrossRef]

6. Shainyan, B.A.; Kleinpeter, E. Conformational preferences of $\mathrm{Si}-\mathrm{Ph}, \mathrm{H}$ and $\mathrm{Si}-\mathrm{Ph}, \mathrm{Me}$ silacyclohexanes and 1,3-thiasilacyclohexanes. Additivity of conformational energies in 1,1-disubstituted heterocyclohexanes. Tetrahedron 2012, 68, 114-125. [CrossRef]

7. Bushweller, C.H. Conformational Behaviour of Six-Membered Rings: Analysis, Dynamics and Stereoelectronic Effects; Juaristi, E., Ed.; VCH Publisher: New York, NY, USA, 1995; Chapter 2; pp. 25-58.

8. Eliel, E.L.; Wilen, S.H.; Mander, L.N. Stereochemistry of organic compounds; Wiley: New York, NY, USA, 1994; Chapter 11; pp. 665-834.

9. Girichev, G.V.; Giricheva, N.I.; Bodi, A.; Gudnason, P.I.; Jonsdottir, S.; Kvaran, Á.; Arnason, I.; Oberhammer, H. Unexpected conformational properties of 1-trifluoromethyl-1-silacyclohexane $\mathrm{C}_{5} \mathrm{H}_{10} \mathrm{SiHCF}_{3}$ : Gas electron diffraction, low-temperature NMR spectroscopic studies, and quantum chemical calculations. Chem. Eur. J. 2007, 13, 1776-1783. [CrossRef]

10. Bodi, A.; Kvaran, Á.; Jonsdottir, S.; Antonsson, E.; Wallevik, S.Ó.; Arnason, I.; Belyakov, A.V.; Baskakov, A.A.; Hölbling, M.; Oberhammer, H. Conformational Properties of 1-Fluoro-1-silacyclohexane, $\mathrm{C}_{5} \mathrm{H}_{10} \mathrm{SiHF}$ : Gas Electron Diffraction, Low-Temperature NMR, Temperature-Dependent Raman Spectroscopy, and Quantum Chemical Calculations. Organometallics 2007, 26, 6544-6550. [CrossRef]

11. Belyakov, A.V.; Baskakov, A.A.; Naraev, V.N.; Rykov, A.N.; Oberhammer, H.; Arnason, I.; Wallevik, S.Ó. Molecular structure and conformational preferences of 1-chloro-1-silacyclohexane, $\mathrm{CH}_{2}\left(\mathrm{CH}_{2} \mathrm{CH}_{2}\right)_{2} \mathrm{SiH}-\mathrm{Cl}$, as studies by gas-phase electron diffraction and quantum chemistry. Russ. J. Gen. Chem. 2011, 81, 2257-2261. [CrossRef]

12. Belyakov, A.V.; Baskakov, A.A.; Naraev, V.N.; Rykov, A.N.; Oberhammer, H.; Arnason, I.; Wallevik, S.Ó. Molecular structure and conformational preferences of 1-bromo-1-silacyclohexane, $\mathrm{CH}_{2}\left(\mathrm{CH}_{2} \mathrm{CH}_{2}\right)_{2} \mathrm{SiH}$ - $\mathrm{Br}$, as studies by gas-phase electron diffraction and quantum chemistry. Russ. J. Phys. Chem. A. 2011, 86, 1563-1566. [CrossRef]

13. Belyakov, A.V.; Baskakov, A.A.; Berger, R.J.F.; Mitzel, N.W.; Oberhammer, H.; Arnason, I.; Wallevik, S.Ó. Molecular structure and conformational preferences of gaseous 1-iodo-1-silacyclohexane. J. Mol. Struct. 2012, 1012, 126-130. [CrossRef]

14. Weldon, A.; Tschumper, G.S. Intrinsic conformational preferences of and an anomeric-like effect in 1-substituted silacyclohexanes. Int. J. Quant. Chem. 2007, 107, 2261-2265. [CrossRef]

15. Wallevik, S.Ó.; Bjornsson, R.; Kvaran, Á.; Jonsdottir, S.; Arnason, I.; Belyakov, A.V.; Baskakov, A.A.; Hassler, K.; Oberhammer, H. Conformational Properties of 1-Silyl-1-Silacyclohexane, $\mathrm{C}_{5} \mathrm{H}_{10} \mathrm{SiHSiH}_{3}$ : Gas Electron Diffraction, Low-Temperature NMR, Temperature-Dependent Raman Spectroscopy, and Quantum Chemical Calculations. J. Phys. Chem. A 2010, 114, 2127-2135. [CrossRef]

16. Belyakov, A.V.; Sigolaev, Y.; Shlykov, S.A.; Wallevik, S.Ó.; Jonsdottir, N.R.; Bjornsson, R.; Jonsdottir, S.; Kvaran, Á.; Kern, T.; Hassler, K.; et al. Conformational properties of 1-tert-butyl-1-silacyclohexane, $\mathrm{C}_{5} \mathrm{H}_{10} \mathrm{SiH}(t-\mathrm{Bu})$ : Gas-phase electron diffraction, temperature dependent Raman spectroscopy, and quantum chemical calculations. Struct. Chem. 2015, 26, 445-453. [CrossRef]

17. Shen, Q.; Rhodes, S.; Cochran, J.C. Molecular structure and conformation of cyclohexylsilane as determined by gas-phase electron diffraction. Organometallics 1992, 11, 485-486. [CrossRef] 
18. Wallevik, S.Ó.; Bjornsson, R.; Kvaran, Á.; Jonsdottir, S.; Girichev, G.V.; Giricheva, N.L.; Hassler, K.; Arnason, I. Conformational properties of 1-fluoro-1-methyl-silacyclohexane and 1-methyl-1-trifluoromethyl-1-silacyclohexane: Gas electron diffraction, low-temperature NMR, temperature-dependent Raman spectroscopy, and quantum chemical calculations. J. Mol. Struct. 2010, 978, 209-219. [CrossRef]

19. Allinger, N.L.; Tribble, M.T. Conformational analysis-LXXVIII. The conformation of phenyl-cyclohexane, and related molecules. Tetrahedron Lett. 1971, 12, 3259-3262. [CrossRef]

20. Wiberg, K.B.; Castejon, H.; Bailey, W.F.; Ochterski, J. Conformational studies in the cyclohexane series. 2. Phenylcyclohexane and 1-methyl-1-phenylcyclohexane. J. Org. Chem. 2000, 65, 1181-1187. [CrossRef]

21. Mazaleyrat, J.P.; Welvart, Z. Non-additivity of the conformational free-energy differences of 1-substituted cyclohexylamines. J. Chem. Soc. D Chem. Comm. 1969, 485-486. [CrossRef]

22. Sicsic, S.; Welvart, Z. Conformational gem-effect in disubstituted cyclohexanes. Chem. Comm. 1966, 499-500. [CrossRef]

23. Uebel, J.J.; Goodwin, H.W. Conformational analysis of 1-methylcyclohexanol. J. Org. Chem. 1968, 33, 3317-3319. [CrossRef]

24. Allinger, N.L.; Liang, C.D. Conformational analysis. LXIII. The 1-methylcyclohexanol system. J. Org. Chem. 1968, 33, 3319-3321. [CrossRef]

25. Eliel, E.L.; Enanoza, R.M. Conformational analysis. XXVI. Conformational equilibria in 5,5-disubstituted 1,3-dioxanes. J. Am. Chem. Soc. 1972, 94, 8072-8081. [CrossRef]

26. Eliel, E.I.; Manoharan, M. Conformational analysis. 40. Conformation of 1-methyl-1-phenylcyclohexane and conformational energies of the phenyl and vinyl groups. J. Org. Chem. 1981, 46, 1959-1962. [CrossRef]

27. Allinger, N.L.; Liang, C.D. Conformational analysis. LVI. Chlorocyclohexane and 1-chloro-1-methylcyclohexane. J. Org. Chem. 1967, 32, 2391-2394. [CrossRef]

28. Schneider, H.-J.; Hoppen, V. Carbon-13 nuclear magnetic resonance substituent-induced shieldings and conformational equilibriums in cyclohexanes. J. Org. Chem. 1978, 43, 3866-3873. [CrossRef]

29. Klaeboe, P.; Nielsen, C.J.; Horn, A.; Guirgis, G.A.; Overby, J.S.; Aleksa, V. Raman and infrared spectra, quantum chemical calculations, conformations and spectral assignments of 1-chloro-1-methyl-1-silacyclohexane. J. Mol. Struct. 2013, 1047, 282-291. [CrossRef]

30. Shainyan, B.A.; Kirpichenko, S.V.; Kleinpeter, E. Synthesis and conformational properties of 1,3-dimethyl-3-phenyl-1,3-azasilinane. Low temperature dynamic NMR and computational study. Arkivoc 2012, 2012, 175-185.

31. Kirpichenko, S.V.; Shainyan, B.A.; Kleinpeter, E. Unusual conformational preferences of 1,3-dimethyl-3-isopropoxy-3-silapiperidine. J. Phys. Org. Chem. 2012, 25, 1321-1327. [CrossRef]

32. Shainyan, B.A.; Kirpichenko, S.V.; Kleinpeter, E.; Shlykov, S.A.; Osadchiy, D.Y. Molecular structure and conformational analysis of 3-methyl-3-phenyl-3-silatetrahydropyran. Gas-phase electron diffraction, low temperature NMR and quantum chemical calculations. Tetrahedron 2015, 71, 3810-3818. [CrossRef]

33. Shainyan, B.A.; Kirpichenko, S.V.; Kleinpeter, E. Stereochemistry of 3-isopropoxy-3-methyl-1,3-oxasilinane-The first 3-silatetrahedropyran with an exocyclic RO-Si bond. Tetrahedron 2015, 71, 6720-6726. [CrossRef]

34. Kirpichenko, S.V.; Shainyan, B.A.; Kleinpeter, E.; Shlykov, S.A.; Phien, T.D.; Albanov, A.I. Synthesis of 3-fluoro-3-methyl-3-silatetrahydropyran and its conformational preferences in gas and solution by GED, NMR and theoretical calculations. Tetrahedron 2018, 74, 1859-1867. [CrossRef]

35. Kirpichenko, S.V.; Kleinpeter, E.; Ushakov, I.A.; Shainyan, B.A. Conformational Analysis of 3-Methyl-3-silathiane and 3-Fluoro-3-methyl-3-silathiane. J. Phys. Org. Chem. 2011, 24, 320-326. [CrossRef]

36. Noll, J.E.; Daubert, B.F.; Speier, J.L. Effect of organic Si substituents on the basic strength of amines. J. Am. Chem. Soc. 1951, 73, 3871-3873. [CrossRef]

37. Sommer, L.H.; Rockett, J. Polar effects of organic Si substituents in aliphatic amines. J. Am. Chem. Soc. 1951, 73, 5130-5134. [CrossRef]

38. Zingler, G.; Kelling, H.; Popowski, E. Untersuchungen zur Basizitat von Alkyl- and Silylalkylaminen IIZ. Z. Anorg. Allg. Chem. 1981, 476, 41-54. [CrossRef]

39. Vashchenko, A.V.; Abramov, A.V.; Frolov, Y.L. The fine difference in electronic structure of heteroatoms in methyl vinyl ether and sulfide. J. Mol. Struct. Theochem 2002, 594, 107-111. [CrossRef] 
40. Shainyan, B.A.; Suslova, E.N.; Phien, T.D.; Shlykov, S.A.; Heydenreich, M.; Kleinpeter, E. 1-Methylthio-1-phenyl-1-silacyclohexane: Synthesis, conformational preferences in gas and solution by GED, NMR and theoretical calculations. Tetrahedron 2019, 75, 130677. [CrossRef]

41. Kirpichenko, S.V.; Kleinpeter, E.; Shainyan, B.A. Conformational analysis of 3,3-dimethyl-3-silathiane, 2,3,3-trimethyl-3-silathiane and 2-trimethylsilyl-3,3-dimethyl-3-silathiane - Preferred conformers, barriers to ring inversion and substituent effects. J. Phys. Org. Chem. 2010, 23, 859-865. [CrossRef]

42. Anteunis, M.J.O.; Dedeyne, R. ${ }^{1} \mathrm{H}$ nmr study and conformation of 3,3-dimethyl-3-sila-1-heterocyclo-hexanes and derivatives (heteroatom $\mathrm{SiCl}_{2}, \mathrm{SiMe}_{2}, \mathrm{O}, \mathrm{NMe}, \mathrm{S}, \mathrm{Se}, \mathrm{Te}$ ). Org. Magn. Res. 1977, 9, 127-132. [CrossRef]

43. Kitching, W.; Olszowy, H.A.; Drew, G.M.; Adcock, W. Conformational preference of the trimethylsilyl group. J. Org. Chem. 1982, 47, 5153-5156. [CrossRef]

44. Freeman, F.; Phornvoranunt, A.; Hehre, W.J. Molecular orbital study of the conformational energies (- $\Delta \mathrm{G}$ degrees or A values) of 2- alkyltetrahydro-2H-thiopyrans (tetrahydrothiopyrans, thiacyclohexanes, thianes). J. Phys. Org. Chem. 1999, 12, 176-186. [CrossRef]

45. Juaristi, E.; Ordonez, M. Conformational preference of the sulfinyl group in six-membered heterocycles. In Organosulfur Chemistry; Page, P., Ed.; Springer: Berlin, Germany, 1998; Chapter 3; pp. 63-95.

46. Lambert, J.B.; Bailey, D.S.; Mixan, C.E. The persistence of the 1-axial preference in thianes. J. Org. Chem. 1972, 37, 377-382. [CrossRef]

47. Barbarella, G.; Dembech, P.; Tugnoli, V. ${ }^{13} \mathrm{C}$ and ${ }^{17} \mathrm{O}$ chemical shifts and conformational analysis of monoand di-methyl-substituted thiane 1-oxide and thiane 1,1-dioxide. Org. Magn. Reson. 1984, 22, 402-407. [CrossRef]

48. Kirpichenko, S.V.; Albanov, A.I.; Pestunovich, V.A. Conformational Behavior of 3,3-dimethyl-3-silathiane 1-oxide and its diastereomeric 2-methyl derivatives. J. Sulf. Chem. 2004, 25, 21-27. [CrossRef]

49. Shainyan, B.A.; Suslova, E.N.; Kleinpeter, E. Conformational Analysis of 4,4-dimethyl-4-silathiane and its S-oxides. J. Phys. Org. Chem. 2011, 24, 1188-1192. [CrossRef]

50. Shainyan, B.A. Computational Study of 4-Fluoro-4-Chloro- and 4-Fluoro-4-Bromo-4-silathiacyclohexane S-Oxides: Effect of Halogen on the $\mathrm{S}=\mathrm{O} \rightarrow \mathrm{Si}$ Intra-molecular Coordination in the Boat and Twist Conformers. Int. J. Quant. Chem. 2007, 107, 189-199. [CrossRef]

51. Pestunovich, V.A.; Larin, M.F.; Sorokin, M.S.; Albanov, A.I.; Voronkov, M.G. Diastereotopy of equatorial fluorines at the trigonal-bipyramidal silicon atom in organyl [ $\beta$-(trifluorosilyl)ethyl]sulfoxide molecules. $J$. Organomet. Chem. 1985, 280, C17-C20. [CrossRef]

52. Shainyan, B.A.; Suslova, E.N.; Kleinpeter, E. Conformational Analysis of N-phenyl- and N-trifyl-4,4-dimethyl-4-silathiane 1-sulfimides. J. Phys. Org. Chem. 2011, 24, 698-704. [CrossRef]

53. Jalsovszky, I.; Kucsman, Á.; Ruff, F.; Koritsánszky, T.; Argay, G.; Kálmán, A. Conformational analysis of thiane-1 imides: An x-ray study of thiane-1-tosylimide and diastereoisomeric 2-alkyl- and 4-phenylthiane-1-tosylimides. J. Mol. Struct. 1987, 156, 165-192. [CrossRef]

54. Lazareva, N.F.; Shainyan, B.A.; Kleinpeter, E. 4-Alkyl-2,2,6,6-tetramethyl-1,4,2,6-oxaazadisilinanes: Synthesis, structure, and conformational analysis. J. Phys. Org. Chem. 2010, 23, 84-89. [CrossRef]

55. LeMaster, C.B.; LeMaster, C.L.; Tafazzoli, M.; Suarez, C.; True, N.S. Pressure- and temperature-dependent proton NMR studies of N-methylmorpholine ring inversion. J. Phys. Chem. 1990, 94, 3461-3466. [CrossRef]

56. Lunazzi, L.; Casarini, D.; Cremonini, M.A.; Anderson, J.E. The effect of exocyclic conjugation on the inversion of a saturated sox-membered ring. A dynamic NMR study of N-substituted morpholines. Tetrahedron 1991, 47, 7465-7470. [CrossRef]

57. Shainyan, B.A.; Suslova, E.N.; Kleinpeter, E. Conformational Analysis of 4,4-dimethyl-1 -(trifluoromethylsulfonyl)-1,4-azasilinane and 2,2,6,6-tetramethyl-4-(trifluoromethylsulfonyl)-1,4,2,6-oxazadis ilinane. J. Phys. Org. Chem. 2012, 25, 83-90. [CrossRef]

58. Shainyan, B.A.; Ushakov, I.A.; Koch, A.; Kleinpeter, E. Stereodynamics of 1-(Methylsulfonyl)-3, 5-Bis(trifluoromethylsulfonyl)-1,3,5-Triazinane: Experimental and Theoretical Analysis. J. Org. Chem. 2006, 71, 7638-7642. [CrossRef]

59. Shainyan, B.A.; Ushakov, I.A.; Mescheryakov, V.I.; Schilde, U.; Koch, A.; Kleinpeter, E. The stereodynamics of 3,5-bis(trifluoromethylsulfonyl)-1,3,5-oxadiazi nane and 1,3,5-tris(trifluoromethylsulfonyl)-1,3,5-triazinane-An Experimental and Theoretical Study. Tetrahedron 2007, 63, 11828-11837. [CrossRef] 
60. Shainyan, B.A.; Ushakov, I.A.; Mescheryakov, V.I.; Koch, A.; Kleinpeter, E. Variable temperature NMR and theoretical study of the stereodynamics of 5-trifluoromethylsulfonyl-1,3,5-dioxaazinane: Perlin effect subject to heteroatom substitution. Tetrahedron 2008, 64, 5379-5383. [CrossRef]

61. Tacke, R.; Heinrich, T.; Bertermann, R.; Burschka, C.; Hamacher, A.; Kassack, M.U. Sila-haloperidol: A Silicon Analogue of the Dopamine $\left(\mathrm{D}_{2}\right)$ Receptor Antagonist Haloperidol. Organometallics 2004, 23, 4468-4477. [CrossRef]

62. Heinrich, T.; Burschka, C.; Penka, M.; Wagner, B.; Tacke, R. 4-Silapiperidine and 4-silapiperidinium derivatives: Syntheses and structural characterization. J. Organometal. Chem. 2005, 690, 33-47. [CrossRef]

63. Ilg, R.; Burschka, C.; Schepmann, D.; Wünsch, B.; Tacke, R. Synthesis and Pharmacological Characterization of Sila-panamesine, a Sila-Analogue of the $\sigma$ Receptor Ligand Panamesine (EMD 57445). Organometallics 2006, 25, 5396-5408. [CrossRef]

64. Tacke, R.; Nguyen, B.; Burschka, C.; Lippert, W.P.; Hamacher, A.; Urban, C.; Kassack, M.U. Sila-Trifluperidol, a Silicon Analogue of the Dopamine $\left(\mathrm{D}_{2}\right)$ Receptor Antagonist Trifluperidol: Synthesis and Pharmacological Characterization. Organometallics 2010, 29, 1652-1660. [CrossRef]

65. Fischer, M.; Tacke, R. Synthesis of 4-Silapiperidine Building Blocks with N-H Groups Using the Staudinger Reaction. Organometallics 2013, 32, 7181-7185. [CrossRef]

66. Shainyan, B.A.; Kirpichenko, S.V.; Kleinpeter, E.; Shlykov, S.A.; Osadchiy, D.Y.; Chipanina, N.N.; Oznobikhina, L.P. 1,3-Dimethyl-3-silapiperidine: Synthesis, Molecular Structure, and Conformational Analysis by Gas-Phase Electron Diffraction, Low Temperature NMR, IR and Raman Spectroscopy, and Quantum Chemical Calculations. J. Org. Chem. 2013, 78, 3939-3947. [CrossRef] [PubMed]

67. Eliel, E.L.; Kandasamy, D.; Yen, C.-Y.; Hargrave, K.D. Conformational analysis. 39. Carbon-13 NMR spectra of saturated heterocycles. 9. Piperidine and N-methylpiperidine. J. Am. Chem. Soc. 1980, 102, 3698-3707. [CrossRef]

68. Shainyan, B.A.; Kirpichenko, S.V.; Shlykov, S.A.; Kleinpeter, E. Structure and Conformational Properties of 1,3,3-trimethyl-1,3-Azasilinane: Gas Electron Diffraction, Dynamic NMR and Theoretical Study. J. Phys. Chem. A 2012, 116, 784-789. [CrossRef]

69. Shainyan, B.A.; Kirpichenko, S.V.; Kleinpeter, E. Synthesis and conformational analysis of 1,3-azasilinanes. Tetrahedron 2012, 26, 7494-7501. [CrossRef]

70. Lazareva, N.F.; Shainyan, B.A.; Schilde, U.; Chipanina, N.N.; Oznobikhina, L.P.; Albanov, A.I.; Kleinpeter, E. Synthesis, Molecular Structure, Conformational Analysis, and Chemical Properties of Silicon-Containing Derivatives of Quinolizidine. J. Org. Chem. 2012, 77, 2382-2388. [CrossRef]

71. Shainyan, B.A.; Kirpichenko, S.V.; Chipanina, N.N.; Oznobikhina, L.P.; Kleinpeter, E.; Shlykov, S.A.; Osadchiy, D.Y. Synthesis and Conformational Analysis of 3-Methyl-3-silatetrahydropyran by GED, FTIR, NMR, and Theoretical Calculations: Comparative Analysis of 1-Hetero-3-methyl-3-silacyclohexanes. J. Org. Chem. 2015, 80, 12492-12500. [CrossRef]

72. Shainyan, B.A.; Kirpichenko, S.V.; Kleinpeter, E. Conformational preferences of the Ph Group in 1-Phenyl-1-X-1-silacyclo-hexanes $(X=\mathrm{MeO}, \mathrm{HO})$ and 3-Ph-3-X-3-silatetrahydropyrans $(X=\mathrm{HO}, \mathrm{H})$ by LTe ${ }^{13}$ C-NMR Spectroscopy and Theoretical Calculations. J. Org. Chem. 2017, 82, 13414-13422. [CrossRef]

73. Wallevik, S.Ó.; Bjornsson, R.; Kvaran, Á.; Jonsdottir, S.; Arnason, I.; Belyakov, A.V.; Kern, T.; Hassler, K. Conformational Properties of 1-Halogenated-1-Silacyclohexanes, $\mathrm{C}_{5} \mathrm{H}_{10} \mathrm{SiHX}(\mathrm{X}=\mathrm{Cl}, \mathrm{Br}$, I): Gas Electron Diffraction, Low-Temperature NMR, Temperature-Dependent Raman Spectroscopy, and Quantum-Chemical Calculations. Organometallics 2013, 32, 6996-7005. [CrossRef]

74. Belyakov, A.V.; Sigolaev, Y.F.; Shlykov, S.A.; Wallevik, S.Ó.; Jonsdottir, N.R.; Jonsdottir, S.; Kvaran, Á.; Bjornsson, R.; Arnason, I. Conformational properties of 1-cyano-1-silacyclohexane, $\mathrm{C}_{5} \mathrm{H}_{10} \mathrm{SiHCN}$ : Gas electron diffraction, low-temperature NMR and quantum chemical calculations. J. Mol. Struct. 2017, 1132, 149-156. [CrossRef]

75. Shlykov, S.A.; Puchkov, B.V.; Arnason, I.; Wallevik, S.Ó.; Giricheva, N.I.; Girichev, G.V.; Zhabanov, Y.A. 1-Methoxy-1-silacyclohexane: Synthesis, molecular structure and conformational behavior by gas electron diffraction, Raman spectroscopy and quantum chemical calculations. J. Mol. Struct. 2018, 1154, 156-570. [CrossRef] 
76. Shainyan, B.A.; Belyakov, A.V.; Sigolaev, Y.F.; Khramov, A.N.; Kleinpeter, E. Molecular Structure and Conformational Analysis of 1-Phenyl-1-X-1-Silacyclohexanes (X = F, Cl) by Electron Diffraction, Low-Temperature NMR, and Quantum Chemical Calculations. J. Org. Chem. 2017, 82, 461-470. [CrossRef] [PubMed]

77. Suslova, E.N.; Shainyan, B.A. 1-Phenyl-1-halo-1-silacyclohexanes. Russ. J. Gen. Chem. 2016, 86, $1854-1858$. [CrossRef]

78. Phien, T.D.; Kuzmina, L.E.; Kvaran, Á.; Jonsdottir, S.; Arnason, I.; Shlykov, S.A. Cyanocyclohexane: Axial-to-equatorial "seesaw" parity in gas and condensed phases. J. Mol. Struct. 2018, 1168, 127-134. [CrossRef]

79. Shlykov, S.A.; Osadchiy, D.Y.; Chipanina, N.N.; Oznobikhina, L.P.; Shainyan, B.A. Molecular structure and conformational analysis of 3-methyl-3-silathiane by gas phase electron diffraction, FT-IR spectroscopy and quantum chemical calculations. J. Mol. Struct. 2015, 1100, 555-561. [CrossRef]

80. Shainyan, B.A.; Kirpichenko, S.V.; Osadchiy, D.Y.; Shlykov, S.A. Molecular structure and conformations of 1-phenyl-1-silacyclohexane from gas-phase electron diffraction and quantum chemical calculations. Struct. Chem. 2014, 25, 1677-1685. [CrossRef]

81. Phien, T.D.; Shlykov, S.A.; Shainyan, B.A. Molecular structure and conformational behavior of 1-methyl-1-phenylsilacyclohexane studied by gas electron diffraction, IR spectroscopy and quantum chemical calculations. Tetrahedron 2017, 73, 1127-1134. [CrossRef]

82. Wiberg, K.B.; Lambert, K.M.; Bailey, W.F. The Role of $\mathrm{CH} \cdots \mathrm{O}$ Coulombic Interactions in Determining Rotameric Conformations of Phenyl Substituted 1,3-Dioxanes and Tetrahydropyrans. J. Org. Chem. 2015, 80, 7884-7889. [CrossRef]

83. Phien, T.D.; Kuzmina, L.E.; Suslova, E.N.; Shainyan, B.A.; Shlykov, S.A. Conformational rivalry of geminal sub-stituents in silacyclohexane derivatives: 1-phenyl vs. 1-OR, $\mathrm{R}=\mathrm{H}$ or Me. Tetrahedron 2019, 75, 3038-3045. [CrossRef]

84. Suslova, E.N.; Shainyan, B.A. 1-Phenyl-1-X-1-silacyclohexanes (X $\left.=\mathrm{MeO}, \mathrm{OH}, \mathrm{Me}_{2} \mathrm{~N}\right)$. Russ. J. Gen. Chem. 2017, 87, 1645-1648. [CrossRef]

85. Shainyan, B.A.; Suslova, E.N.; Phien, T.D.; Shlykov, S.A.; Kleinpeter, E. Synthesis, conformational preferences in gas and solution, and molecular gear rotation in 1-(dimethylamino)-1-phenyl-1-silacyclohexane by gas phase electron diffraction (GED), LT NMR and theoretical calculations. Tetrahedron 2018, 74, 4299-4307. [CrossRef]

86. Shainyan, B.A.; Kleinpeter, E.; Suslova, E.N. Conformational Analysis of $\left(1,1^{\prime}\right.$-Phenyl-1,1'-silacyclohex-1-yl)disiloxane. DFT and Low-Temperature ${ }^{13} \mathrm{C}$ NMR Spectroscopy Study. Russ. J. Gen. Chem. 2019, 89, 713-716. [CrossRef]

87. Kleinpeter, E.; Shainyan, B.A. Very low temperature dynamic ${ }^{29} \mathrm{Si}$ NMR study of the conformational equilibrium of (1,1'-phenyl-1,1'-silacyclohex-1-yl)disiloxane. Magn. Res. Chem. 2019, 89, 713-716.

88. Suslova, E.N.; Shainyan, B.A. 4,4-Dimethyl-3,4-dihydro-2H-1,4-thiasiline - the first cyclic organosilicon vinyl sulfide. Mendeleev Commun. 2013, 23, 255-256. [CrossRef]

89. Jensen, F.R.; Bushweller, C.H. Conformational preferences and interconversion barriers in cyclohexene and derivatives. J. Am. Chem. Soc. 1969, 91, 5774-5782. [CrossRef]

90. Anet, F.A.L.; Bourn, A.J.R. Nuclear Magnetic Resonance Line-Shape and Double-Resonance Studies of Ring Inversion in Cyclohexane- $d_{11}$. J. Am. Chem. Soc. 1967, 89, 760-768. [CrossRef]

91. Shainyan, B.A.; Kleinpeter, E. Conformational flexibility of 4,4-dimethyl-3,4-dihydro-2H-1,4-thiasiline and its monoheterocyclic analogs. Russ. J. Gen. Chem. 2014, 84, 1129-1133. [CrossRef]

92. Suslova, E.N.; Shainyan, B.A. Synthesis of 4, 4-diphenyl-3, 4-dihydro-2H-1, 4-thiasiline. Sulfur Chem. 2014, 35, 641-648. [CrossRef]

93. Suslova, E.N.; Shainyan, B.A. S-functional derivatives of 3,4-dihydro-2H-1,4-thiasilines. Russ. J. Gen. Chem. 2015, 85, 2743-2747. [CrossRef]

(C) 2020 by the author. Licensee MDPI, Basel, Switzerland. This article is an open access article distributed under the terms and conditions of the Creative Commons Attribution (CC BY) license (http://creativecommons.org/licenses/by/4.0/). 